\title{
GROUND-WATER LEVELS AND POTENTIOMETRIC SURFACES, NAVAL AIR WARFARE CENTER, WEST TRENTON, NEW JERSEY, 2000
}

Water-Resources Investigations Report 01-4197

Version 1.1, August 2018

Prepared in cooperation with the U.S. Navy 


\section{GROUND-WATER LEVELS AND POTENTIOMETRIC SURFACES, NAVAL AIR WARFARE CENTER, WEST TRENTON, NEW JERSEY, 2000}

By Pierre J. Lacombe

U.S. Geological Survey

Water-Resources Investigations Report 01-4197

Version 1.1, August 2018

Prepared in cooperation with the U.S. Navy

West Trenton, New Jersey

2002

Revised: August 2018

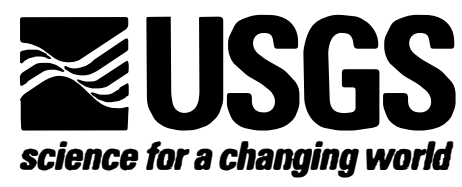




\title{
U.S. DEPARTMENT OF THE INTERIOR \\ RYAN K. ZINKE, Secretary
}

\author{
U.S. GEOLOGICAL SURVEY \\ James K. Reilly II, Director
}

The use of firm, trade, and brand names in this report is for identification purposes only and does not constitute endorsement by the U.S. Geological Survey.

For additional information

Write to

District Chief

U.S. Geological Survey

3450 Princeton Pike, Suite 110

Lawrenceville, NJ 08648
Copies of this report can be

purchased from

U.S. Geological Survey

Branch of Information Services

Box 25286

Denver, CO 80225-0286 


\section{CONTENTS}

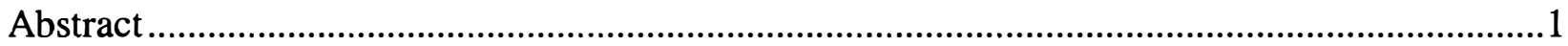

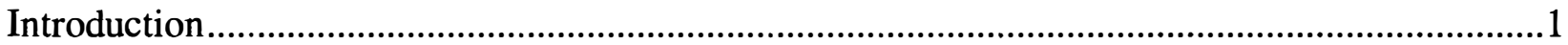

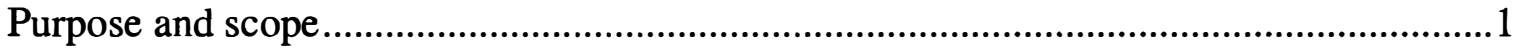

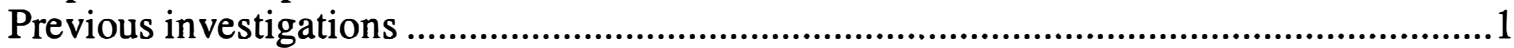

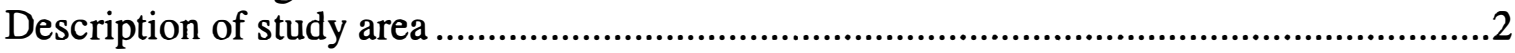

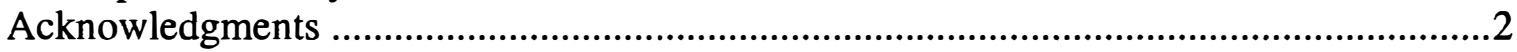

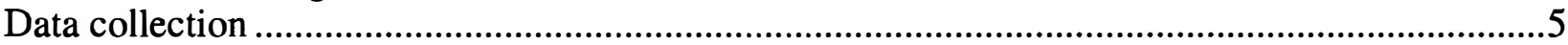

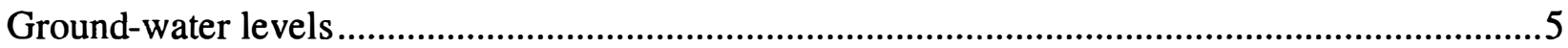

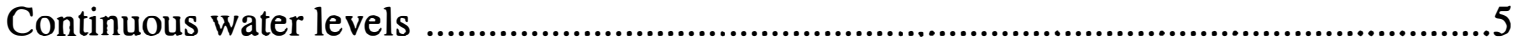

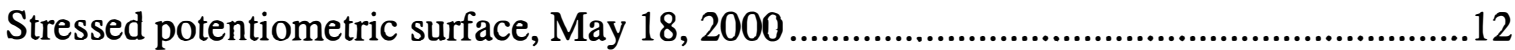

Static potentiometric surface, October 23, 2000 ........................................................21

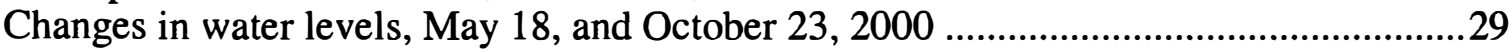

Summary

\section{ILLUSTRATIONS}

Figure 1. Digital orthophoto showing the location of the study area, Naval Air Warfare Center, West Trenton, N.J.

2. Map showing the study area, near surface geology, contamination Sites 1 and 3, and observation wells, Naval Air Warfare Center...

3. Water-level hydrographs for seven wells, Naval Air Warfare Center and precipitation hydrograph for the rain gage at Washington Crossing State Park, Hopewell Township, N.J., 2000.

4. Map showing the stressed potentiometric surface at an altitude of +150 feet (approximately land surface), Naval Air Warfare Center, May 18, 2000, West Trenton, N.J.

5. Map showing the stressed potentiometric surface at an altitude of +50 feet (approximately 100 feet below land surface), May 18, 2000, Naval Air Warfare Center, West Trenton, N.J.

6. Hydrologic sections showing stressed water-level altitudes and potentiometric surface, May 18, 2000, Naval Air Warfare Center, West Trenton, N.J....................16

$\begin{array}{ll}\text { a. } & \text { Section A-A', } \\ \text { b. } & \text { Section B-B' } \\ \text { c. } & \text { Section C-C', } \\ \text { d. } & \text { Section D-D' } \\ \text { e. } & \text { Section E-E' } \\ \text { f. } & \text { Section F-F' } \\ \text { g. Section G-G' } & \text { Section H-H' } \\ \text { h. } & \text { Section I-I' } \\ \text { j. } & \text { Section J-J' }\end{array}$ 


\section{ILLUSTRATIONS--Continued}

Figure 7. Map showing the static potentiometric surface at an altitude of +150 feet (approximately land surface), October 23, 2000, Naval Air Warfare Center, West Trenton, N.J.

8. Map showing the static potentiometric surface at an altitude of +50 feet (approximately 100 feet below land surface), October 23, 2000, Naval Air Warfare Center, West Trenton, N.J.

9. Hydrologic sections showing static water-level altitudes and potentiometric s urface,

October 23, 2000, Naval Air Warfare Center, West Trenton, N.J.

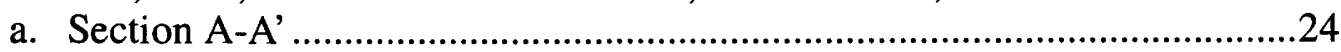

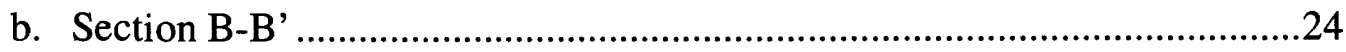

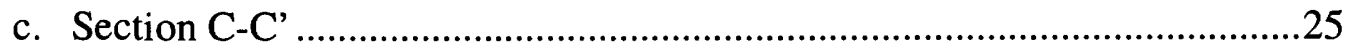

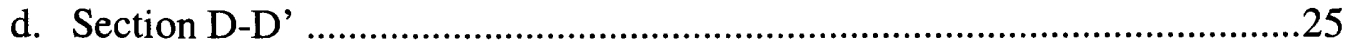

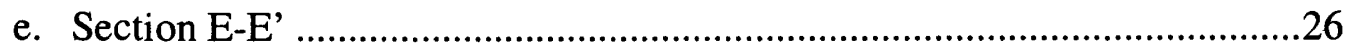

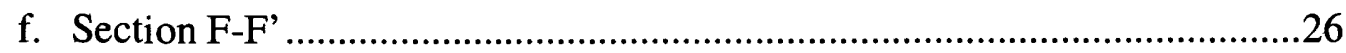

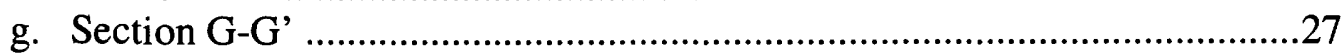

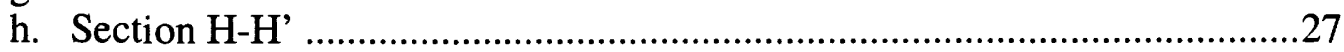

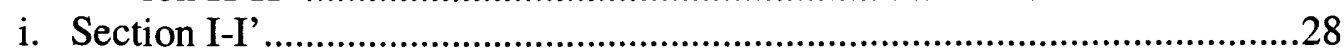

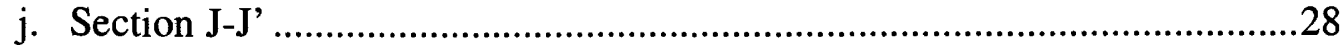

10. Map showing the change in water level at an altitude of +150 feet

(approximately land surface), May 18 to October 23, 2000, Naval Air Warfare

Center, West Trenton, N.J.

11. Map showing the change in water level at an altitude of $+50 \mathrm{feet}$

(approximately 100 feet below land surface), May 18 to October 23, 2000,

Naval Air Warfare Center, West Trenton, N.J.

12. Hydrologic sections showing the change in water levels from May 18 to

October 23, 2000, Naval Air Warfare Center, West Trenton, N.J...........................32

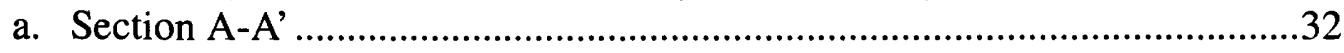

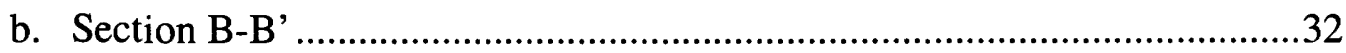

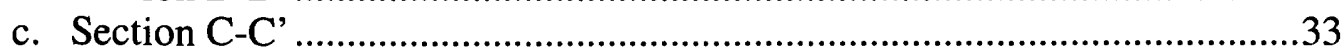

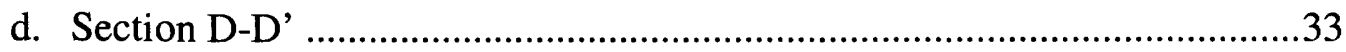

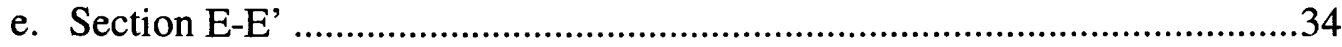

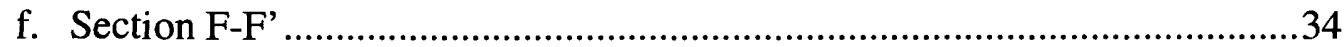

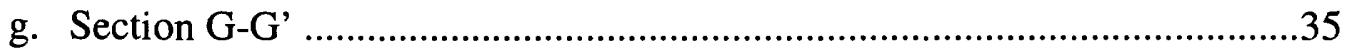

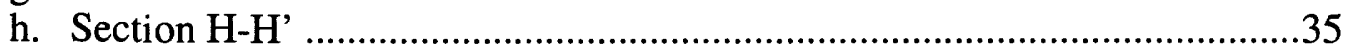

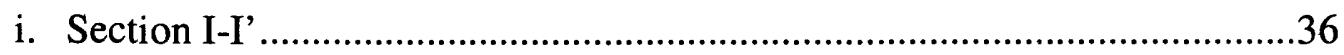

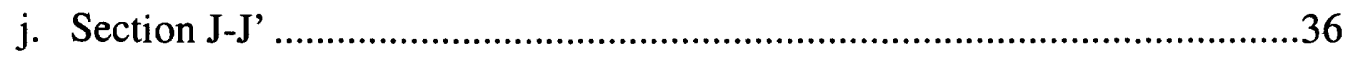

\section{TABLES}

Table 1. Description of, and water-level altitudes in, wells completed in bedrock and shallow wells at the Naval Air Warfare Center, West Trenton, N.J., 1995-2000. 


\title{
CONVERSION FACTORS, VERTICAL DATUM, DEFINITIONS, AND ABBREVIATIONS
}

\author{
Conversion Factors
}

Multiply

inch (in)

foot $(\mathrm{ft})$

mile (mi)
By

Length

2.54

0.3048

1.609

Volume

gallons per minute (gal/min)

gallon (gal)
3.785

3.785
To obtain

centimeter

meter

kilometer

liters per minute

liter

\section{Vertical Datum}

Vertical datum used in this report is the National Geodetic Vertical Datum of 1929--a geodetic datum derived from a general adjustment of the first-order level nets of the United States and Canada, formerly called Sea Level Datum of 1929.

Conversion of National Geodetic Vertical Datum (NGVD) of 1929 to North American Vertical Datum (NAVD) of 1988-Subtract $0.994 \mathrm{ft}$ from the NGVD 1929 value to obtain NAVD 1088. This conversion value only applies to the Naval Air Warfare Center, West Trenton, New Jerrey and the immediate vicinity.

\section{Definitions}

Altitude: In this report "altitude" refers to distance above or below the National Geodetic Vertical Datum of 1929 (NGVD of 1929). The altitude of a point with reference to the NGVD of 1929 is converted to an altitude based on the National Altitude Geodetic Datum of 1989 (NAGD of 1989) by subtracting $0.994 \mathrm{ft}$ from the altitude based on the NGVD of 1929.

Elevation: In this report "elevation" refers to the distance above or below land surface datum.

Sea Level: In this report "sea level" refers to the National Geodetic Vertical Datum of 1929 NGVD 1929 is a geodetic datum derived from a general adjustment of first-order level nets of both the United Sates and Canada, formerly called the Sea Level Datum of 1929.

\section{Abbreviations Used In This Report}

$\begin{array}{ll}\text { NAWC } & \text { Naval Air Warfare Center } \\ \text { USGS } & \text { U.S. Geological Survey }\end{array}$




\title{
GROUND-WATER LEVELS AND POTENTIOMETRIC SURFACES, NAVAL AIR WARFARE CENTER, WEST TRENTON, NEW JERSEY, 2000
}

\author{
By Pierre J. Lacombe
}

\begin{abstract}
Water levels were measured in wells at the decommissioned Naval Air Warfare Center in West Trenton, N.J., during 2000. Water-level hydrographs prepared from data collected at seven observation wells on the base show changes caused by seasonal and daily climate conditions and by the pumping of contaminated water from recovery wells. Stressed and unstressed potentiometric surfaces for 2000 are similar in shape to those during 1995-99, but are not as deep. The greatest differences between the potentiometric surfaces in 2000 and those in 1995-99 were caused by turning off sump pumps in NAWC buildings when the base was closed.
\end{abstract}

\section{INTRODUCTION}

Water levels are measured in wells at the Naval Air Warfare Center (NAWC) in West Trenton, N.J., for the semi-annual water-level monitoring program that is part of the long-term management plan for NAWC overseen by the U.S. Navy. Continuous water-level recorders have been installed in seven wells on the base since 1997 to monitor fluctuations in water levels over long and short terms. Long-term water-level declines occur during summer and water-level rises occur during winter, primarily because of increased and decreased evapotranspiration. Short-term waterlevel fluctuations are the result of precipitation and the turning on and off the pumps in six wells that are used to recover ground water contaminated with trichloroethylene and other compounds.

Knowledge of the water-level fluctuation facilitates the determination of the zone of influ- ence caused by pumping the recovery wells. Waterlevel data also can be used to determine the appropriate location and rate of pumping for the recovery wells to optimize withdrawal of contaminated ground water. To provide the necessary water-level data, the U.S. Geological Survey in cooperation with the U.S. Navy conducted this study during 2000 to measure water levels in wells comp'ted in the bedrock and overburden at NAWC.

\section{Purpose and Scope}

This report documents water-level data on and near the decommissioned NAWC during 2000. Water-level data were measured at 15-minute intervals with automatic data recorders placed in seven wells. Instantaneous water-levels were measured in as many as 100 wells on May 18 and Octoter 23, 2000. Water-level data are presented as maps and sections that show the stressed and unstressed potentiometric surfaces on those dates and as changes in water levels between the two da+es. Water-level data also are shown in hydrographs. Instantaneous water levels in 2000, along with water levels in 1995 and 1999, and water-level changes, are listed in a table, and hydraulic gradients and the zone of influence of the recovery wells are discussed.

\section{Previous Investigations}

Lacombe (2000) describes in detail tre hydrogeologic framework at NAWC and in sludes many maps and sections. His report shows the static potentiometric surface on December 4, 1995, water-level drawdown during aquifer tests on wells 15BR, BRP1, and 5BR, and the stressed po+entiometric surface on August 25 to 27, 1997. International Technology Corporation (1994) cond icted a 
remedial investigation of NAWC and produced static potentiometric-surface maps from water levels measured during July 15 to 21, 1992, and September 9, 1992, in wells completed in shallow bedrock and water levels measured during November 4 to 5,1993 , in wells in shallow and deep bedrock.

The potentiometric-surface maps and sections prepared from water levels on December 4, 1993, and August 25 to 27, 1997, have been presented in reports by EA Engineering, Science, and Technology Inc. (2000a and b). A report by the U.S. Navy (Aug. 2000) includes potentiometric surface maps and sections prepared from water levels measured on May 18, 2000. Unpublished potentiometric-surface maps and sections prepared from measurements made on February 1, 1999, and August 9, 1999, and change in water-level maps and sections from measurements made on August 12,1999 , and October 28, 2000, are on file at the USGS office in West Trenton, N.J. EA Engineering, Science, and Technology, Inc. (1995) published potentiometric-surface maps prepared from data collected on March 9 and March 15, 1995, and from data collected on December 4, 1995 (EA Engineering, Science, and Technology Inc., 1996).

\section{Description of Study Area}

The NAWC is a 65 -acre former military base in west-central New Jersey (fig. 1). The base was decommissioned on October 15, 1998, and it has been divided into three parcels. Each parcel has been or, during 2000 , was in the process of being sold or transferred to private interests or other governmental agencies. The former base is bordered by the Mercer County Airport on the east, north, and west and by Parkway Avenue on the south (fig. 2). Commercial and industrial firms occupy the south side of Parkway Avenue. Freight train tracks separate the eastern from the western part of the base.

The base is in the Piedmont Physiographic Province. Bedrock in the region consists of the Lockatong Formation, which is predominantly mudstone and shale, and the Stockton Formation, which is predominantly sandstone. Lacombe (2000) identified bedding units L-13 to L-23 in the
Lockatong Formation and S-11 to S-15 in the Stockton Formation on the basis of the magnitude of natural gamma-ray signature. A fault with a general strike of $25^{\circ} \mathrm{E}$ crosses the southern part of the base (fig. 2). The natural topography in the area is characterized by low rolling hills; however, much of the base has been leveled and terraced to accommodate the NAWC and the airport runway.

A spring in the wooded area near the southwest corner of NAWC flows nearly all year. The spring forms the headwater of the west branch of Gold Run. Sometime before 1940, the west branch of Gold Run was diverted to the culvert constructed under the eastbound lanes of Park way Ave., and in the 1970's, a second culvert was built under the westbound lanes of Parkway Avenue. The two culverts carry surface- and grounc'-water discharge to the main stem of Gold Run (fig. 2).

The Lockatong Formation, which unterlies the NAWC, is a fractured bedrock aquifer. The static hydraulic gradient in the bedrock aquifer is southward toward the west branch of Gold Run, but the static ground-water-flow direction is westward toward the spring. The stressed hydraulic gradient caused by pumping of the recovery w'ells is anisotropic with a ratio of at least $4: 1$. The preferential flow direction in the bedrock aquifer is along the strike and along the dip plain. Bedding partings control much of the ground-water flow. In this report, the location of the fault was modif'ed on the east side of NAWC. The modified location of the fault on the east side of the base is from 10 to $250 \mathrm{ft}$ south of the location shown in Lacombe (2000).

\section{Acknowledgments}

The author thanks Jeffery Dale of the U.S. Navy and Steve Feldman and his staff at EA Engineering, Science, and Technology, Inc., for assistance in collection of the instantaneous water-level data during this investigation. In addition, the author would like to thank Robert Rosmar of the U.S. Geological Survey for maintaining the continuous water-level data recorders. 


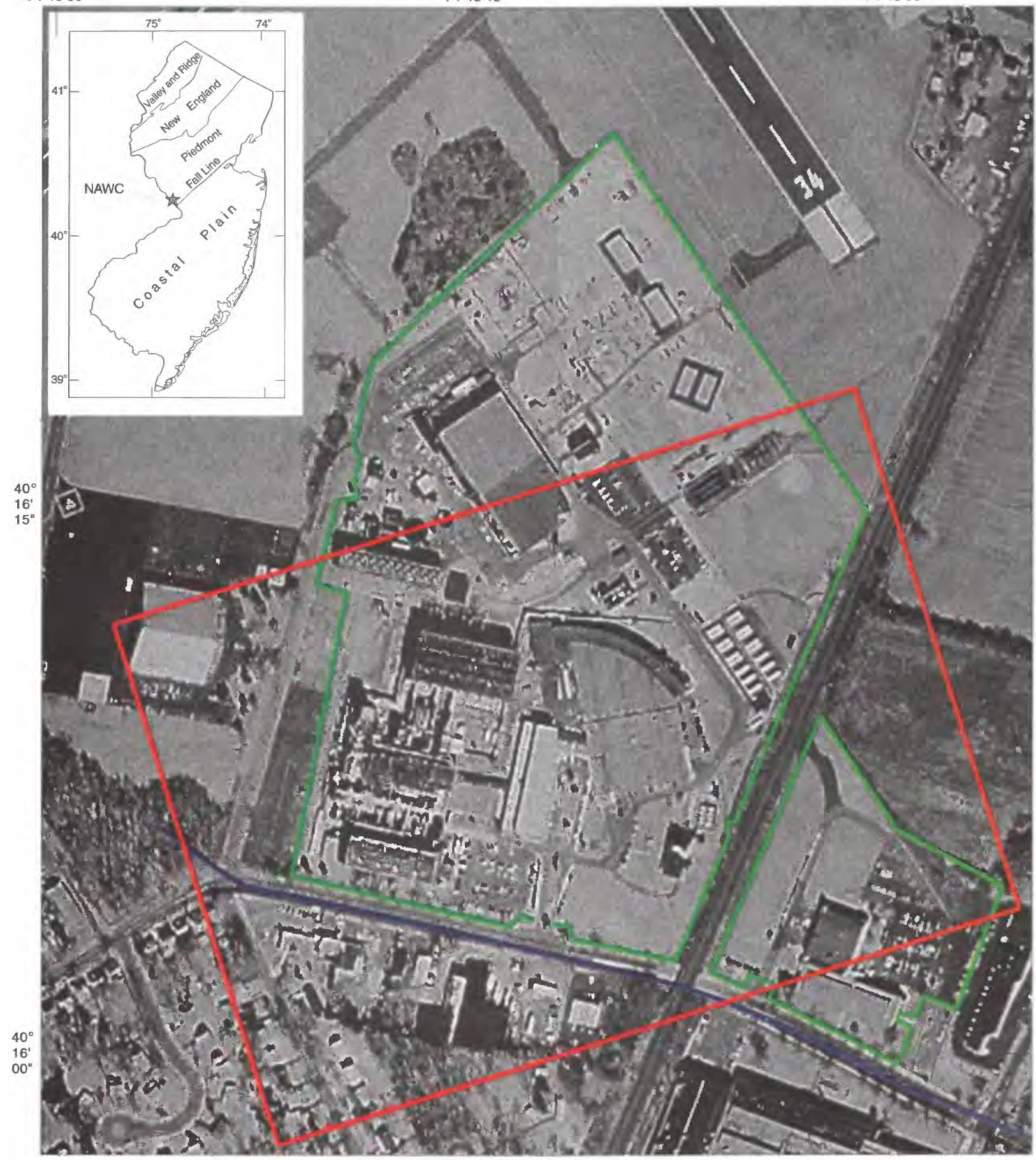

EXPLANATION

- Approximate boundary of the Naval Air Warfare Center

— Study area
$0 \quad 100200 \quad 300 \quad 400$ FEET

$0 \quad 100$ METERS

Figure 1. Digital orthophoto showing the location of the study area, Naval Air Warfare Center (NAWC), West Trenton, N.J. 


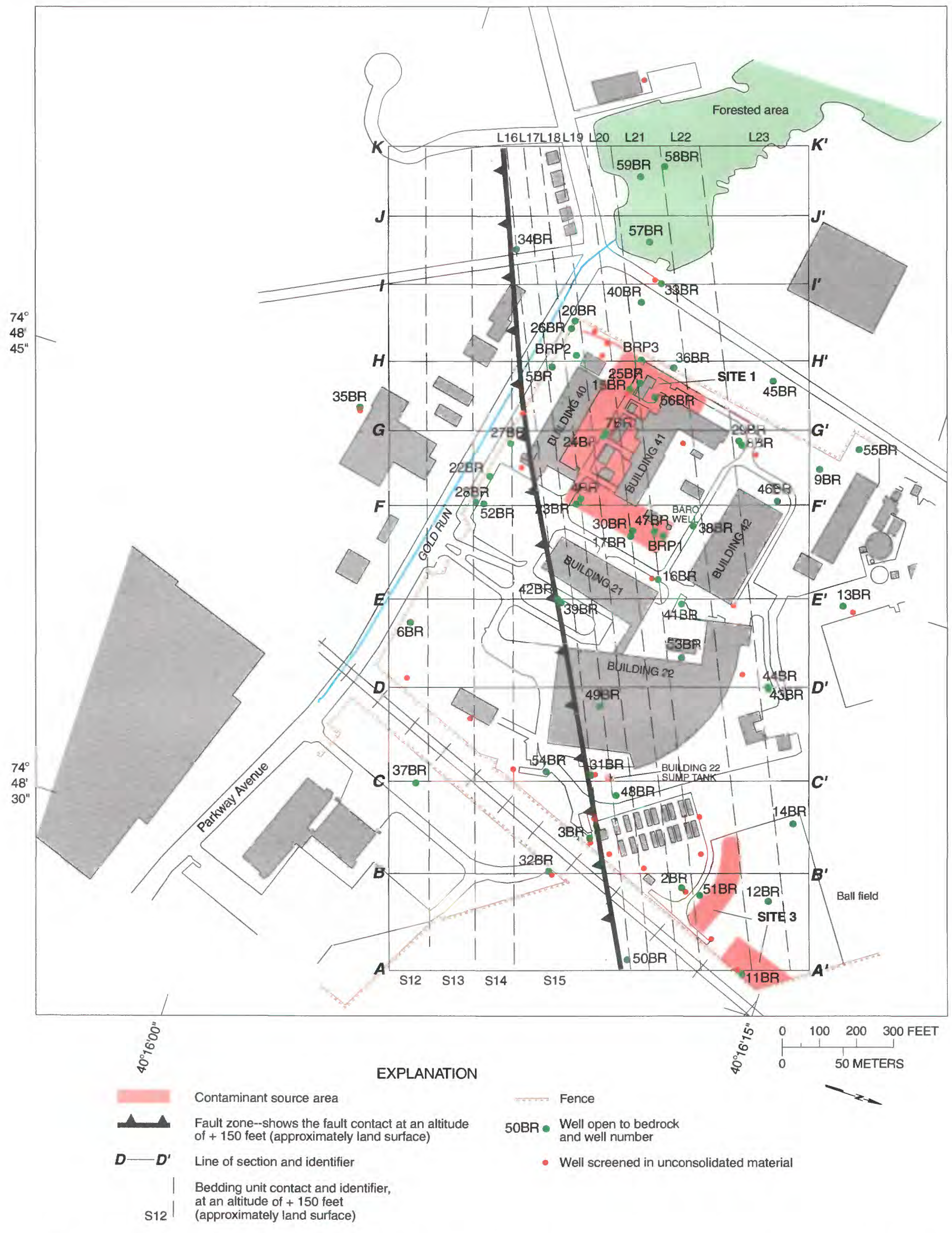

Figure 2. Study area showing the near surface geology, contamination Sites 1 and 3, and observation wells, Naval Air Warfare Center, West Trenton, N.J. 


\section{DATA COLLECTION}

Continuous digital water-level recorders using floats or pressure transducers were installed on seven wells-BRP2, 12 BR, 33BR, 38BR, 40BR, 51BR, and 59BR (fig. 2)-to record water-level fluctuations at 15 -minute intervals. Water-level hydrographs for the seven wells are shown in figure 3. In this report, elevation refers to feet below the land-surface datum, and altitude refers to feet above the sea level datum (NGVD of 1928). The continuous water-level data for each well are on file at the USGS District office in West Trenton, N.J.

Instantaneous water levels were measured in as many as 100 wells from 8:00 am to $4: 30 \mathrm{pm}$ on May 18 and October 23, 2000. It had not rained at NAWC during the 3 days prior to those dates. On May 18, the six wells used to recover contaminated ground water had been in continuous operation for at least 3 days. On October 23, those six wells had not been pumped for at least 3 days.

All water levels were measured with an electric or steel tape with a repeatability of $0.01 \mathrm{ft}$. Water-level data are presented in table 1 . Well locations and well numbers at Sites 1 and 3 are shown in figure 2.

\section{GROUND-WATER LEVELS}

This section includes ground water-level hydrographs, and maps and sections showing the stressed, static, and changes in water levels. Continuous water levels were collected with data recorders during 2000. Stressed water levels were measured while the pumps had been operating continuously for at least 3 days. Static water levels were measured when the pumps were turned off for more than 3 days. Changes in water levels were calculated by subtracting the stressed water levels measured on May 18, 2000, from the static water levels measured on October 23, 2000. The technique used to contour water levels is significantly different from the typically used "map view" technique of contouring. Lacombe (2000) explains in detail how water levels are first contoured in section and map view and then the contours are tentatively modified until the configuration of the potentiometric surface is true in both map view and section view. Lacombe (2000) explains the apparent discrepancies of the method. Offset water-level contours appear incorrect but reflect the location of the contour when projected to the plane of tha map or section.

\section{Continuous Water Levels}

Continuous water-level data were collected to determine the zone of influence created by' pumping recovery wells at NAWC. The specific wells included in the continuous water-level network vary each year to better monitor and interpret the changes in water levels caused by seasonal factors such as rates of evapotranspiration, and by rainfall and pumpage from the recovery wells.

Water-level hydrographs for wells BRP3, 12BR, 33BR, 38BR, 40BR, 51BR, and 59BP (fig. 3 ) show long-term seasonal water-level changes. In addition, the hydrographs show short-term u'aterlevel changes induced by precipitation or pu npage. Short-term peak water levels occurred d"uring a week of heavy rainfall in early August. Longterm seasonal high water levels in February and March are the result of snowmelt and a low rate of evapotranspiration. Seasonal low water levels in mid-July are the result of a high rate of evap transpiration coupled with limited rainfall during early June to mid-July. These seasonal high and lc $\mathrm{N}$ water levels are best observed in the hydrographs for wells BRP3 and 51BR (figs. 3a and 3f) v'hen compared with the precipitation data from W'ashington Crossing State Park (fig. 3h). The sea`onal high and low water levels are less easily obsorved on the other water-level hydrographs. Water-level changes from the seasonal high to seasonal low ranged from 3 to $6 \mathrm{ft}$ in 2000 .

Short-term water-level changes that are the result of rainy and dry periods (fig. $3 \mathrm{~h}$ ) are difficult to separate from short-term water-level changes that are the result of turning the pumps for tho recovery wells off and on (fig. $3 \mathrm{~h}$ ). Few rainy days occurred in February, March, and October, (fg. 3h) although most of the hydrographs show many rises and falls in water levels. Many of the rises and falls are the result of turning off and on the pump as part of planned or unplanned maintenance of the 

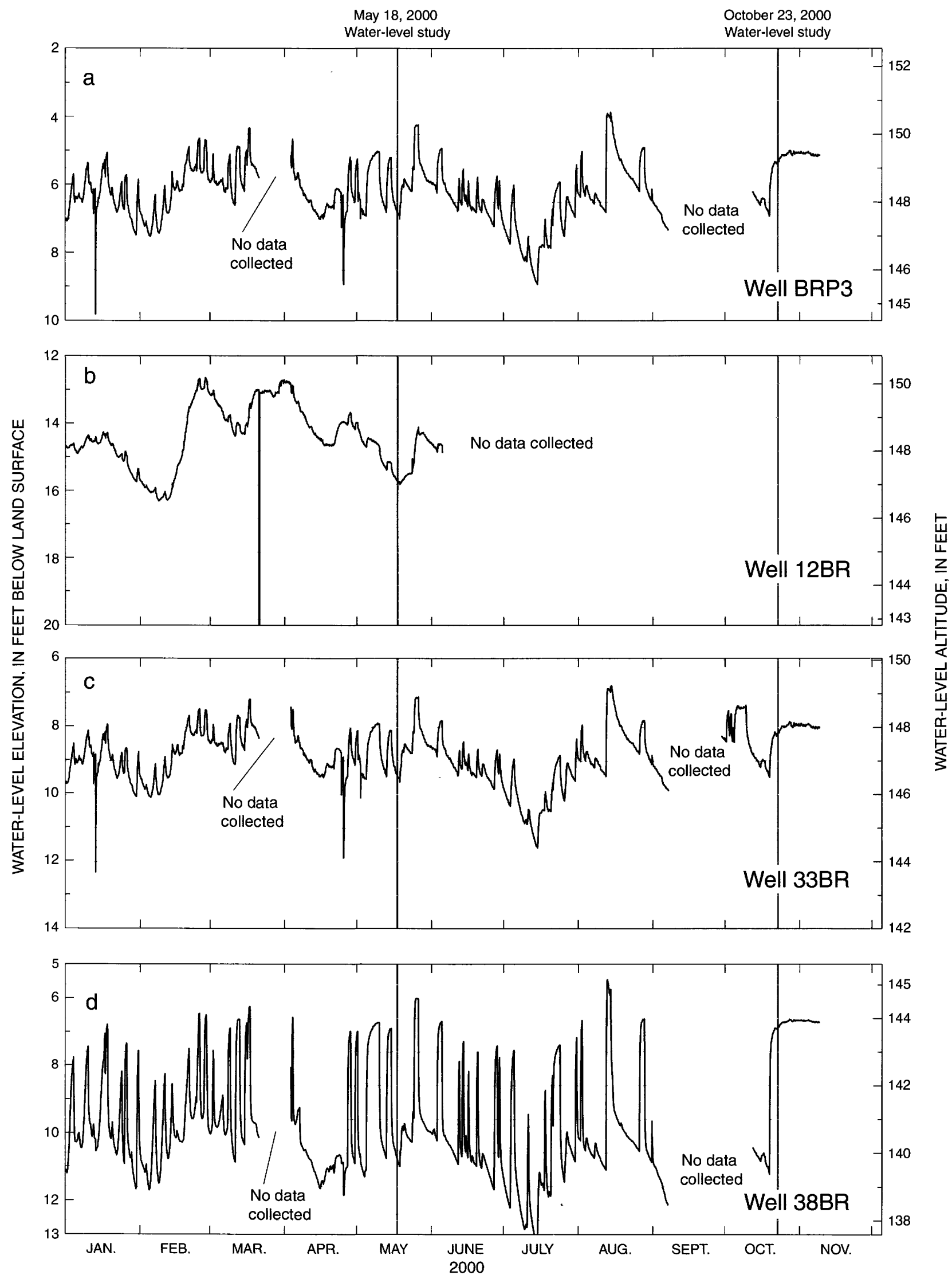

Figure 3. Water-level hydrographs for seven wells, Naval Air Warfare Center and precipitation hydrograph for the rain gage at Washington Crossing State Park, Hopewell Township, N.J., 2000 (see fig.2 for well locations). 

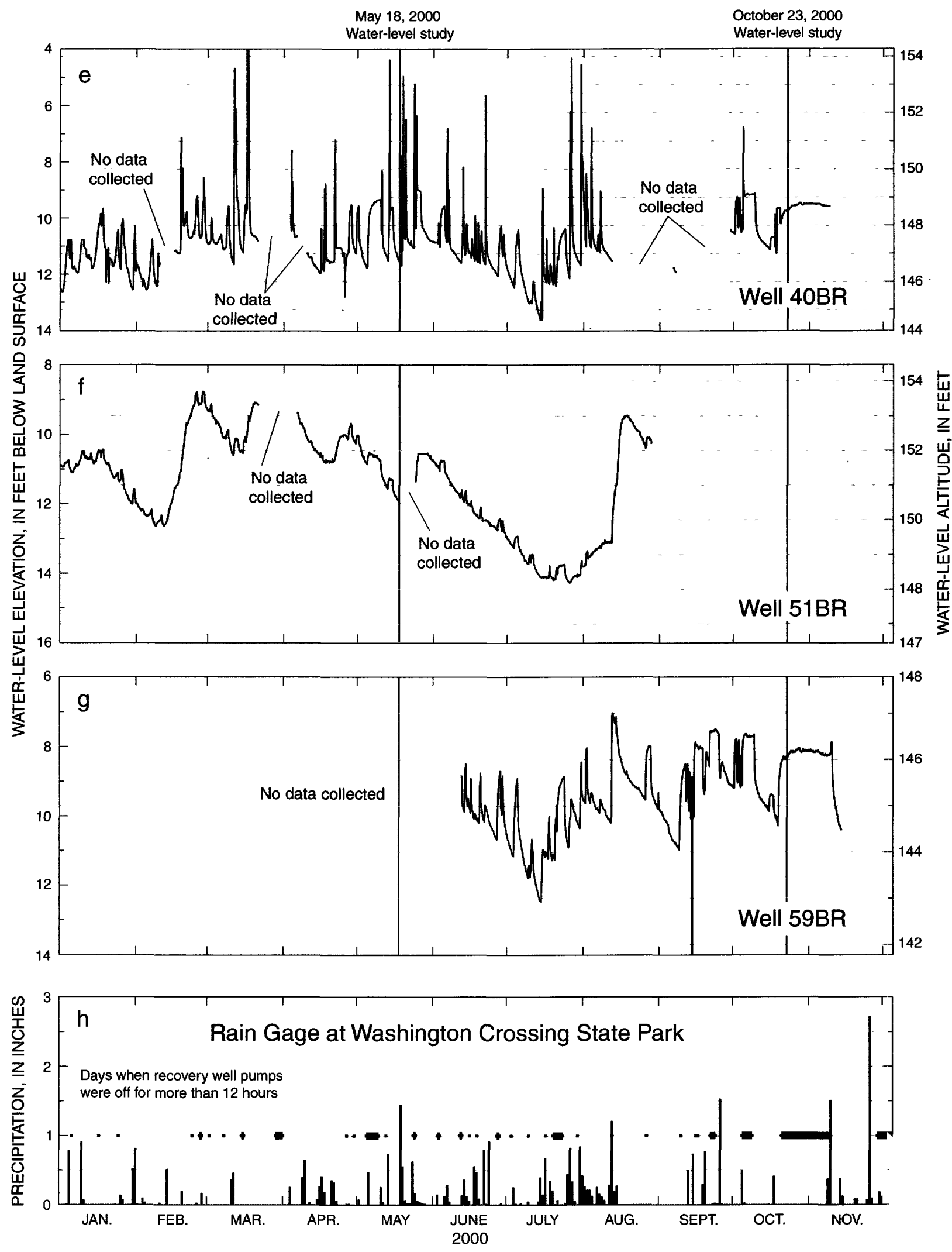

Figure 3. Water-level hydrographs for seven wells, Naval Air Warfare Center and precipitation hydrograph for the rain gage at Washington Crossing State Park, Hopewell Township, N.J., 2000 (see fig. 2 for well locations)--Continued. 


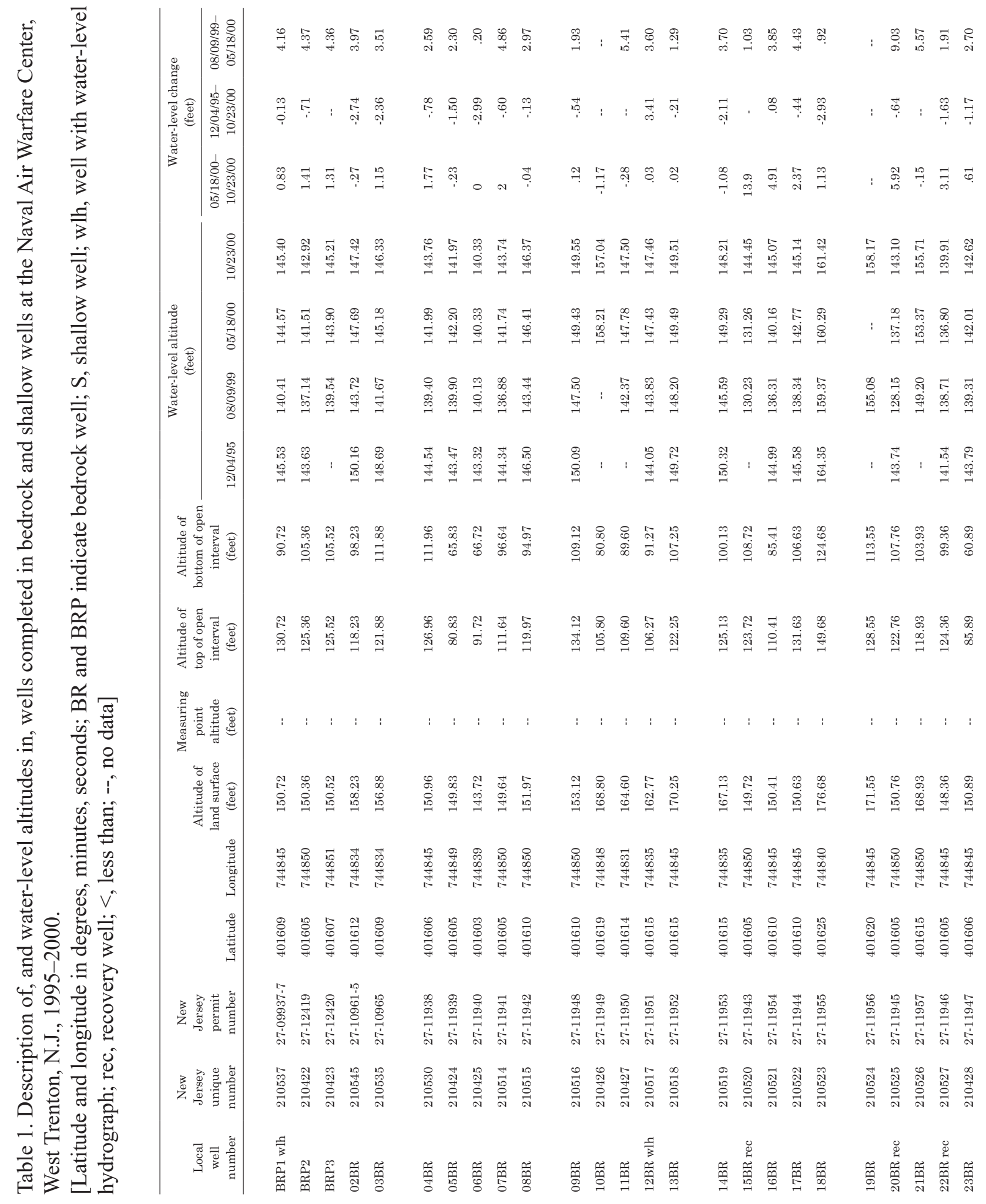




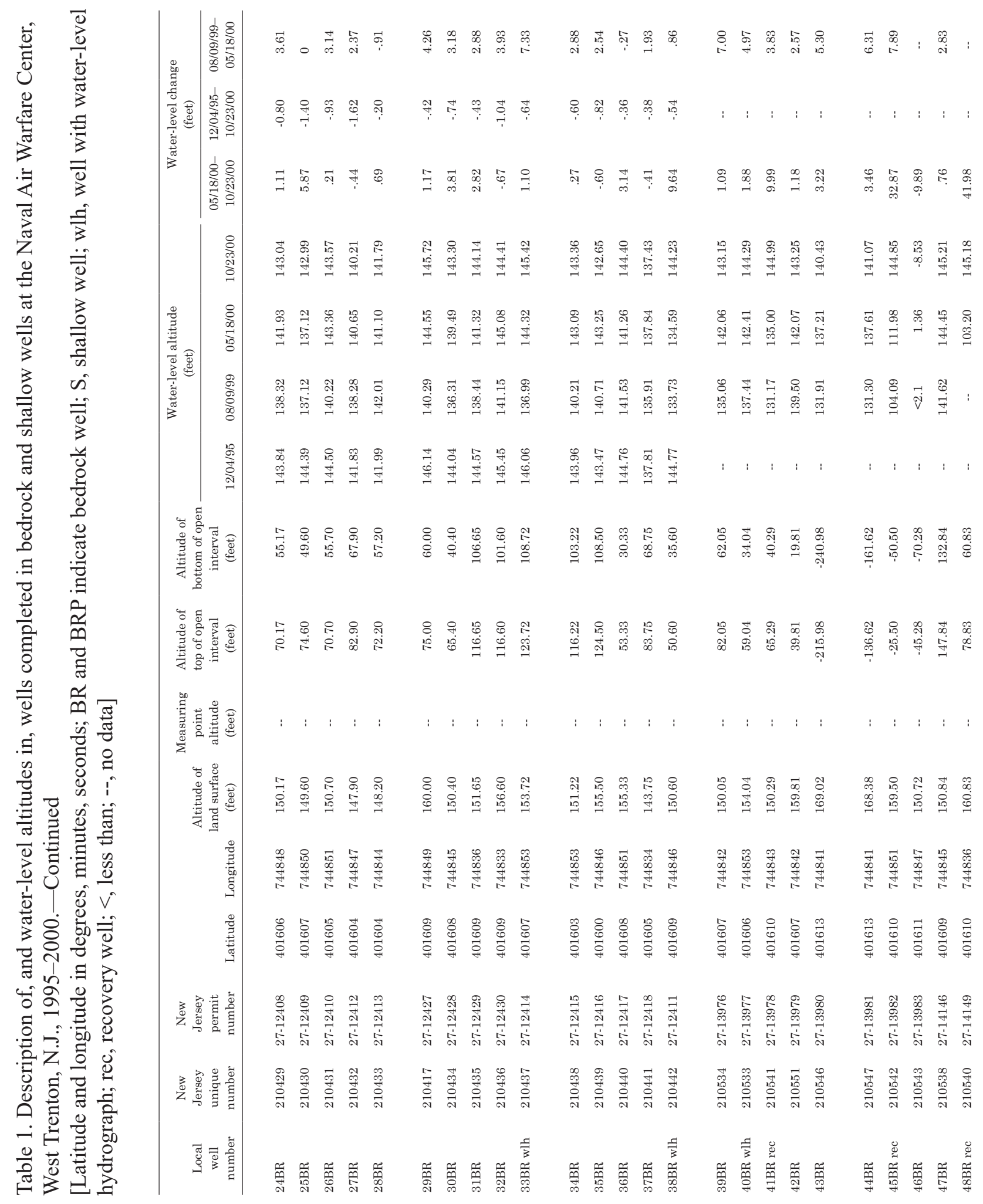




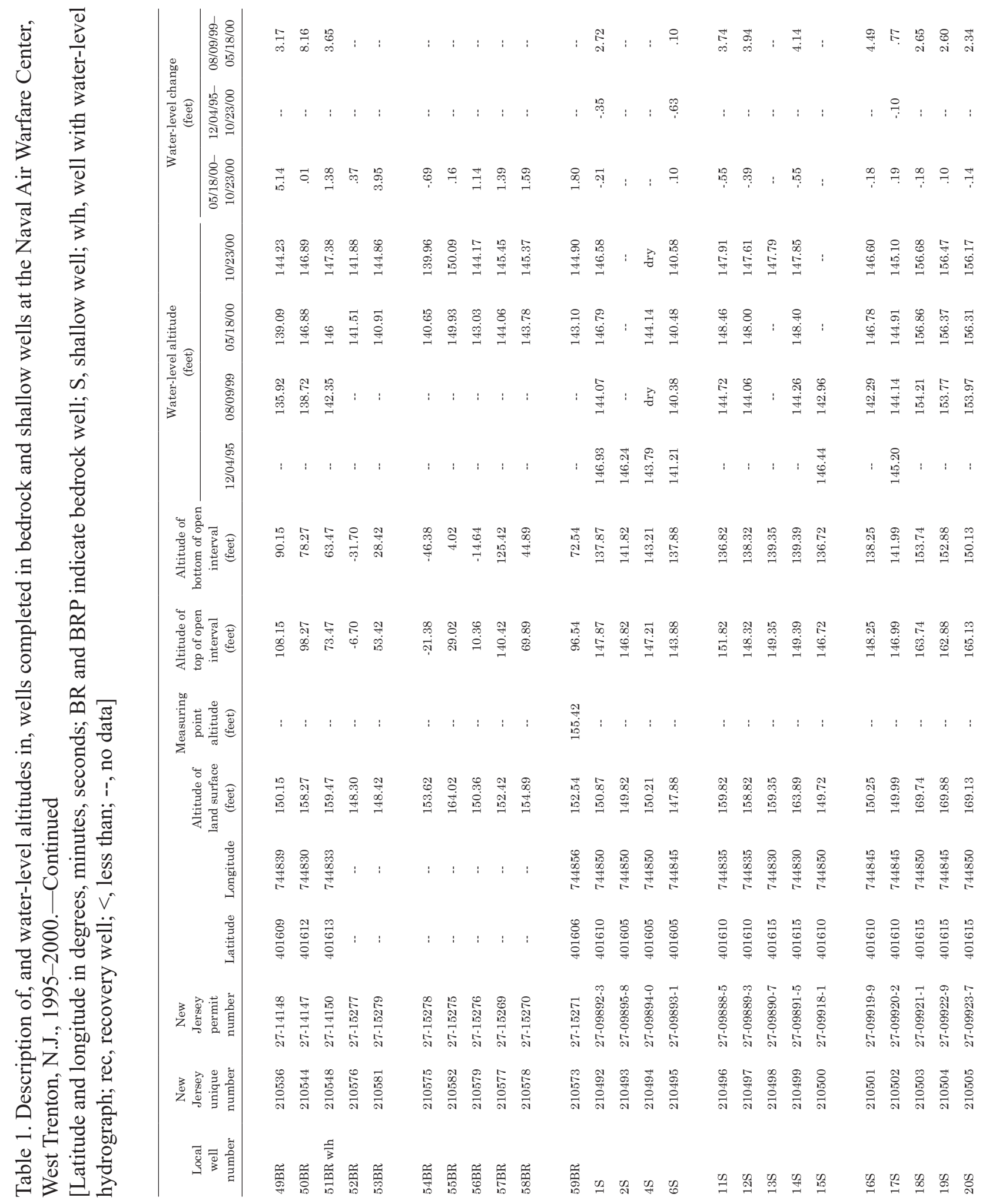




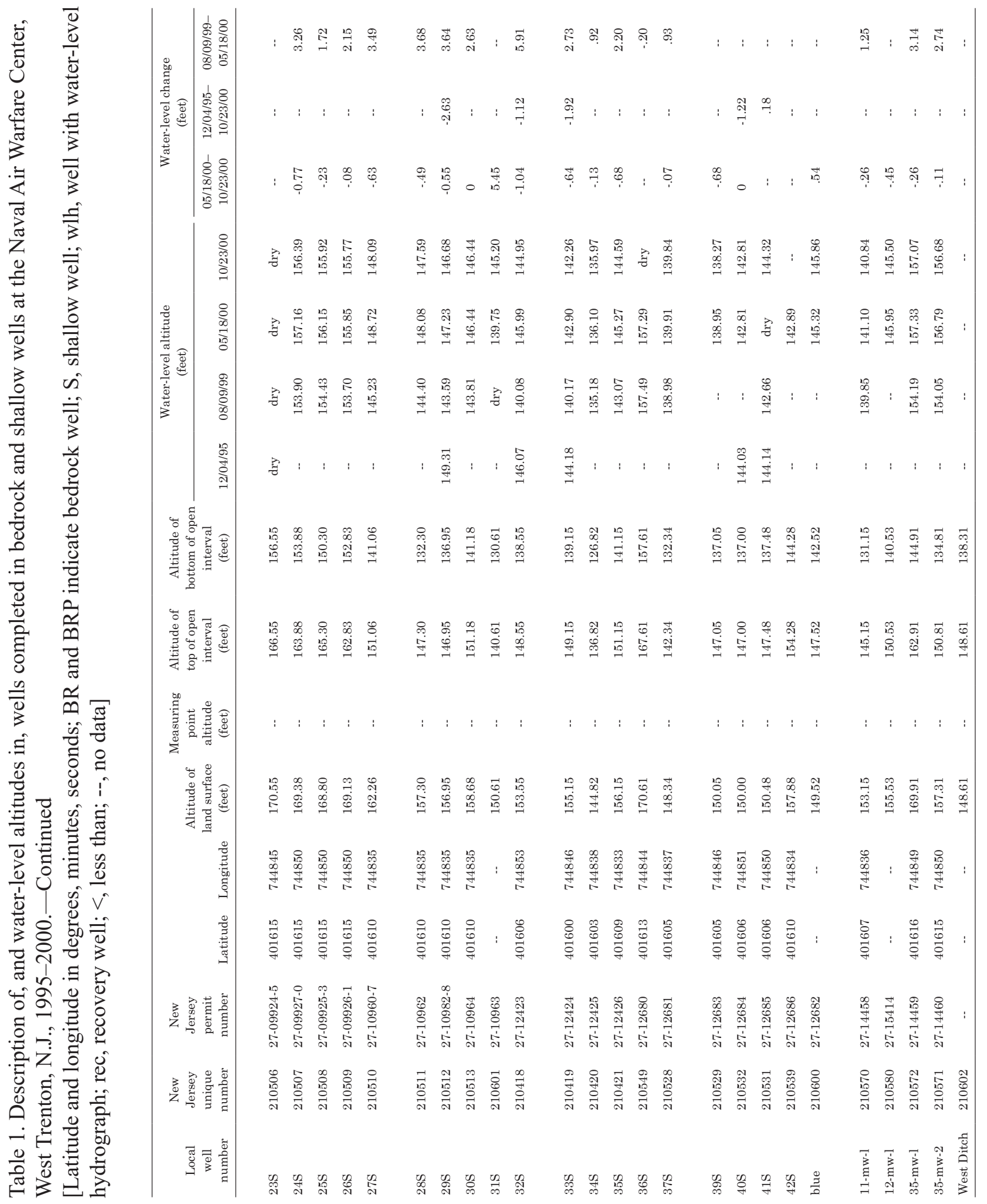


water treatment facility. During early May and late October, the pumps were turned off for about 1 and 3 weeks, respectively. At these times, the peaks of the hydrographs are flat-topped or square-topped, reflecting static unstressed water levels. Other flattopped peaks on the hydrographs are the result of shutting off the pumps and leaving them off for more than one-half day. During early May and late October when the pumps were turned off, the water levels rose about $2 \mathrm{ft}$ in well BRP3, $0.5 \mathrm{ft}$ in well 12BR, $1.5 \mathrm{ft}$ in well 33BR, $4.5 \mathrm{ft}$ in well $38 \mathrm{BR}, 1.5$ $\mathrm{ft}$ in well $40 \mathrm{BR}, 0.5 \mathrm{ft}$ in well $51 \mathrm{BR}$, and $1.5 \mathrm{ft}$ in well 59BR. This rise is a constant for each well when the pumps are turned off. Therefore, rises that are much greater or much less than this value probably are the result of precipitation. In wells BRP3, 12BR, 33BR, 38BR, and 59BR, many of the 1 to $3 \mathrm{ft}$ rises in water levels are the result of rainfall. In well 40BR, many of the 3 to $6 \mathrm{ft}$ rises in water levels are the result of rainfall.

\section{Stressed Potentiometric Surface. May 18, 2000}

Water-level altitudes were measured on May 18,2000 , in 95 wells while pumps in the six recovery wells were running. The resulting water-level data were used to map the stressed potentiometric surface and to determine the extent of the cone of depression created by pumping the six wells at Site 1 and Site 3.

The six recovery wells along with the pumping rate for each well on May 18,2000, are 15BR at $15.0 \mathrm{gal} / \mathrm{min}, 20 \mathrm{BR}$ at $8.5 \mathrm{gal} / \mathrm{min}, 41 \mathrm{BR}$ at $10.0 \mathrm{gal} / \mathrm{min}, 45 \mathrm{BR}$ at $5.1 \mathrm{gal} / \mathrm{min}, 48 \mathrm{BR}$ at $13.5 \mathrm{gal} / \mathrm{min}$, and $22 \mathrm{BR}$ at $4.4 \mathrm{gal} / \mathrm{min}$.

The water-level data were plotted on maps and sections, and contours were drawn (figs. 4-6). Stressed water-level altitudes in the bedrock wells ranged from a maximum of $160.29 \mathrm{ft}$ in well $18 \mathrm{BR}$ at the north side of NAWC to six local minimums, one for each pumping well. Pumping well 48BR had the lowest water-level altitude, $103.20 \mathrm{ft}$ (table 1 ). North of the fault line at land surface, an elongated inclined cone of depression extends almost the length of the study area. The term "inclined cone of depression" is derived from the geologic term "inclined fold," which is a fold in which the axial surface is inclined from the vertical ant in which one limb of the fold may be steeper tl an the other (Hobbs and others, 1976). In this repot, the cone is defined by the 142-ft contour line or the north side and by the fault plain on the soutl $>$ side (fig. 4). Local cones of depression within the elongated inclined cone of depression are caused by pumping wells $15 \mathrm{BR}, 48 \mathrm{BR}$, and $41 \mathrm{BR}$, the three most heavily pumped wells. The minimum waterlevel altitudes at land surface in the elongated cone of depression were about 136 at Site 1 and $140 \mathrm{ft}$ at Site 3. The hydraulic gradient north of the elongated cone of depression is from north-northwest to south-southeast. The direction of preferential ground-water flow was reported by Lacomb (2000) to be nearly along the strike toward the southwest and along the dip plain.

North of the fault at the depth of $100 \mathrm{ft}$ below land surface (fig. 5), the elongated cone of depression is north of its position at land surface, therefore, the inclined attitude of the cone of depression. This attitude is caused by the regional dip of the bedding partings. Again, the low water levels in the deepest part of the cone at this altitude were caused by withdrawals from wells $15 \mathrm{BR}, 48 \mathrm{BR}$, an 1 41BR.

The stressed potentiometric-surface maps and sections for May 18, 2000, are similar to stressed potentiometric-surface maps and sections for August 9, 1999 (EA Engineering. Science, and Technology, 2000a). During summer 1999, a major drought occurred in the region; as a result, ivater levels were much lower in summer 1999 than in summer 2000. Water levels were measured in the same 48 bedrock wells on both dates (table 1). The water-level rise in 45 wells ranged from 0.2 ) to $9.03 \mathrm{ft}$, and the decline in two wells was 0.51 and $0.27 \mathrm{ft}$. The declines occurred in well 36BR, which was pumped continuously, and in well $28 \mathrm{~B}$ P, which is adjacent to well 22BR. A pump initially was turned on in well 22BR on March 2, 2000, and used continuously thereafter.

The following descriptions highlight the changes in each map and section between $\mathrm{t}^{\circ} \cdot$ stressed potentiometric surface of August 9, 1999, and that of May 18, 2000. The stressed potentiometric surface at land surface and $100 \mathrm{ft}$ below 


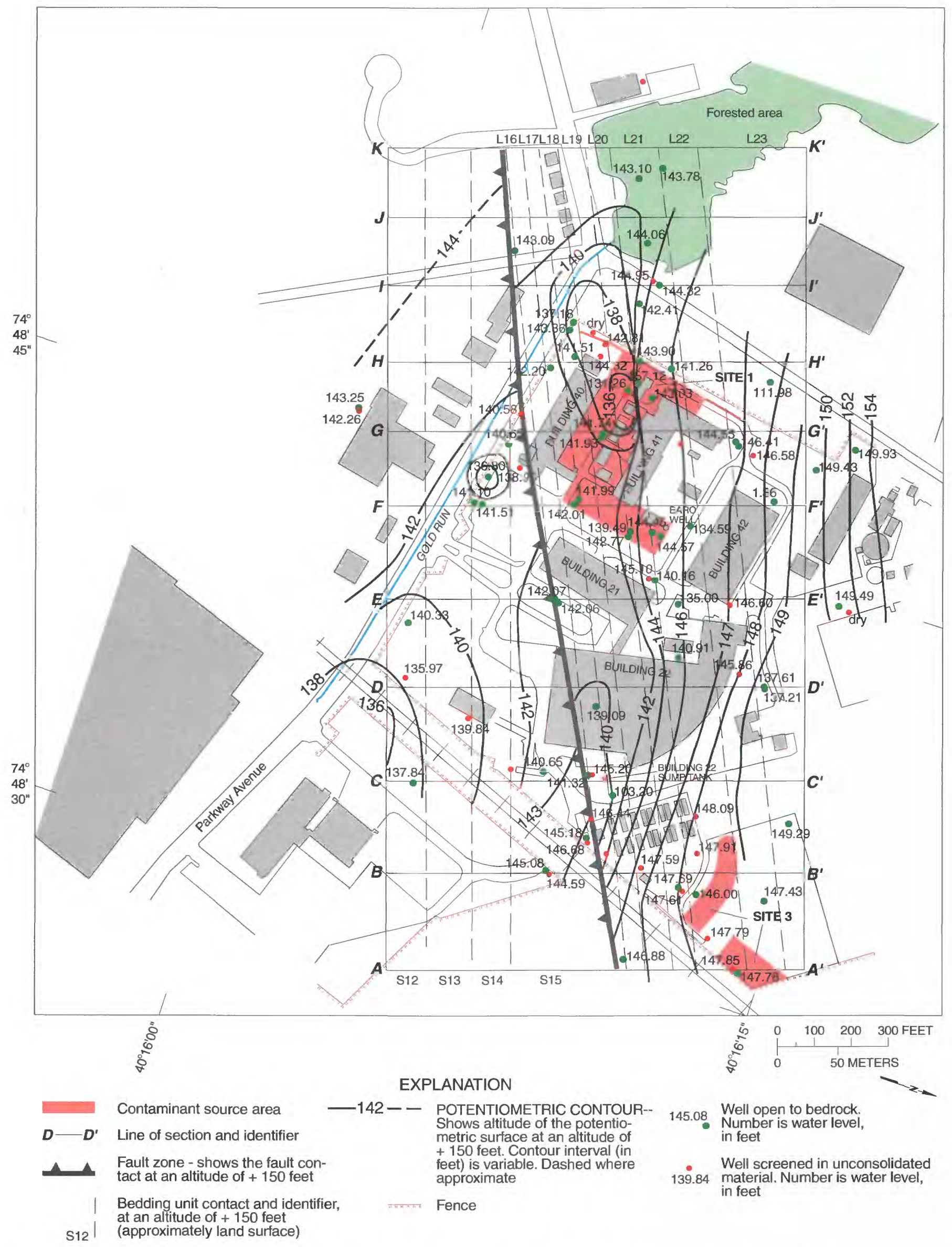

Figure 4. The stressed potentiometric surface at an altitude of +150 feet (approximately land surface), May 18, 2000, Naval Air Warfare Center, West Trenton, N.J. 


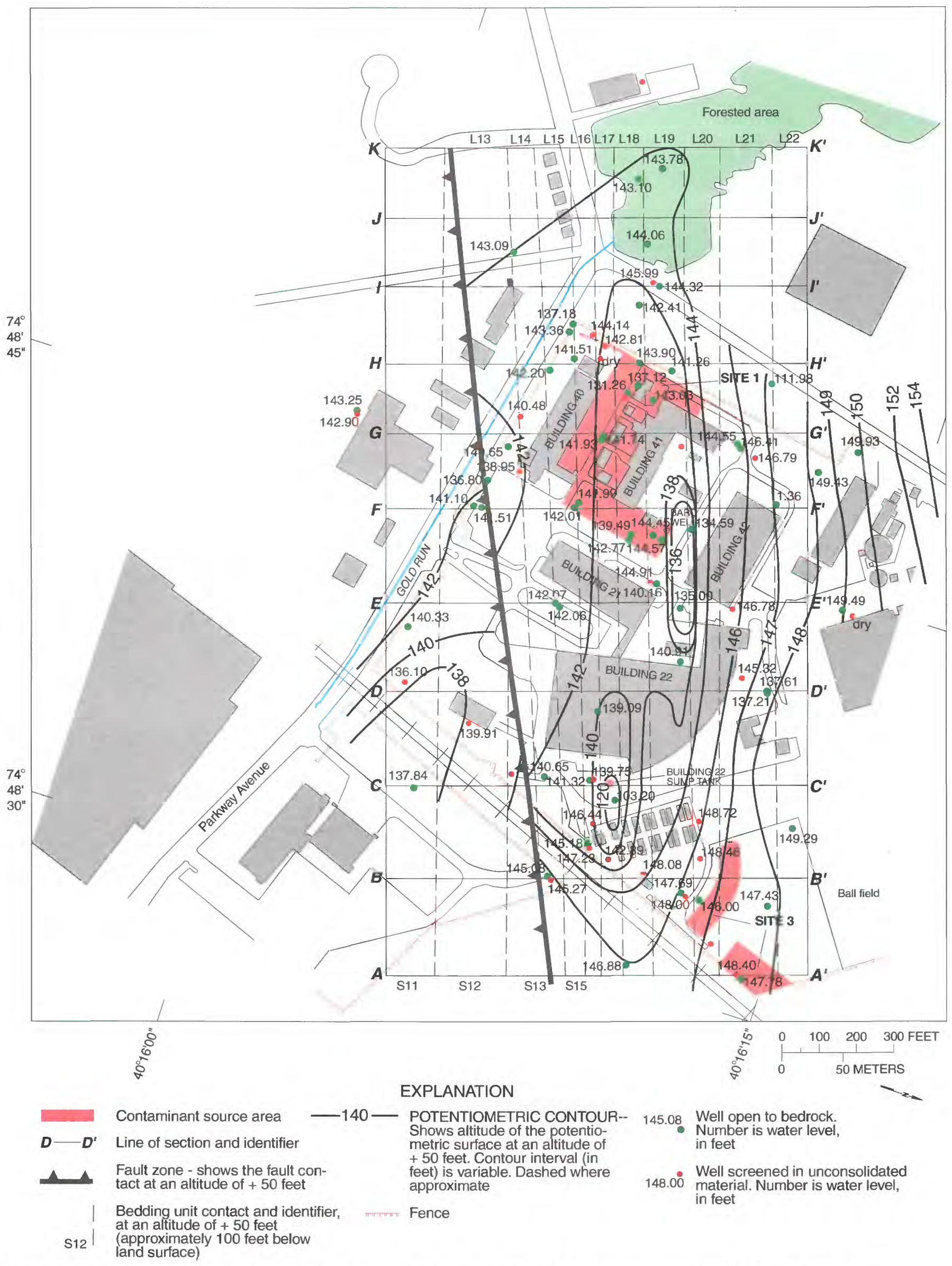

Figure 5. The stressed potentiometric surface at an altitude of +50 feet (approximately 100 feet below land surface), May 18, 2000, Naval Air Warfare Center, West Trenton, N.J. 
land surface for 2000 (figs. 4 and 5) is similar to that for 1999 (EA Engineering, Science, and Technology, 2000a, figs. B-1 and B-2). The inclined cones of depression are in the same location, but they are deeper in 1999 than in 2000 . Changes in the hydraulic gradients between two wells are best observed in the section views (fig. 6a-j). The small water-level mound near wells $4 \mathrm{BR}$ and 23BR probably was caused by a fire hydrant that had been leaking near these wells for about 1 year (fig. $6 f$ ). The potentiometric-contour lines with a "V" shape around the upper reaches of Gold Run (figs. 6e-j) are similar in the 2000 and the 1999 maps. The long contour lines that are parallel to the strike of the bedrock are similar. The contour lines that are between the Site 3 area and building 22 are oblique to the strike of the bedrock.

The stressed potentiometric surface drawn for section A-A' (fig. 6a) (wells 11BR and 50BR) shows a hydraulic gradient of about $1 \mathrm{ft}$ in 2000 and about $3.5 \mathrm{ft}$ in 1999. A water-level recorder placed on wells 11BR and 50BR during 1999 shows a 0.1 - and 1-ft fluctuation, respectively, when the recovery pumps are turned on and off (Lacombe, 1999). On the basis of this water-level data, well 50BR is clearly within the zone of influence of well 48BR; however, the influence of pumping from well 48BR is minimal on the water level in well $11 \mathrm{BR}$. The stressed potentiometric surface for section B-B' (fig 6b) (wells 2BR, $12 \mathrm{BR}$, and 51BR) shows a hydraulic gradient of about $1.5 \mathrm{ft}$ in 2000 similar to that in 1999. A water-level recorder placed on well 51BR during 1999 shows less than a $0.5-\mathrm{ft}$ fluctuation when the pump in well $48 \mathrm{BR}$ is turned off and on (Lacombe, 1999).

The stressed potentiometric surface for section C-C' (fig. 6c) was not directly compared with that in 1999 because water levels were not measured in pumping well 48BR in 1999 and well 54BR had not been installed in 1999. The stressed potentiometric surface for section D-D' (fig. 6d) shows a gradient of about $0.5 \mathrm{ft}$ between well 43BR and 44BR in 2000 that is similar to the gradient shown in 1999. The potentiometric surface in section E-E' (fig. 6e) shows a hydraulic gradient of about $5 \mathrm{ft}$ between well 16BR and 41BR in 2000, which is similar to the gradient in 1999. Virtually no gradient was present between wells $39 \mathrm{~B} R$ and $42 \mathrm{BR}$ in 2000 , but the gradient was nearly $4.5 \mathrm{ft}$ in 1999. It is unclear why the high gradient was present during the drought in 1999 but not in 2000. The potentiometric surface along section F-F' (fig. 6f) in 2000 is similar for the most part to the surface shown in 1999. A major change took place around well 22BR. The pump initially was turned on in this recovery well on March 2, 2000, and it has been operating continuously since this date. Withdrawals have created a small cone of depression in the water-bearing fractures within the Stockton Formation south of the fault and l ave lowered the water level in well $28 \mathrm{BR}$. The gradient between well BRP1 and 38BR was $10 \mathrm{ft}$ in 2000 but was slightly lower, $7 \mathrm{ft}$, in 1999 . The gradient between wells $30 \mathrm{BR}$ and $38 \mathrm{BR}$ was about $5 \mathrm{ft}$ in 2000 and slightly lower, about $2.5 \mathrm{ft}$, in 19?9. It is unclear why the gradient was steeper in 2070 than it was during the drought in 1999. The potentiometric surface along section G-G' (fig. 6g) shows a downward hydraulic gradient between wel $>8 B R$ and 29BR of about $2 \mathrm{ft}$ in 2000 that is similar to the gradient in 1999. The section also shows an upward gradient between wells 24BR and 7BR, but it was only $0.2 \mathrm{ft}$ in 2000 and about $1.5 \mathrm{ft}$ in 1999. It is unclear why the gradient was greater in 1999 than in 2000 . The potentiometric surface in section $\mathrm{H}-\mathrm{H}$ ' (fig. 6h) shows that the inclined cone of depression follows the bedding planes similar to that shown in section F-F'. The inclined contouring pattern is used when delineating the water levels and cones of depression in each of the sect ins at NAWC. Small changes in pumping rates can create large changes in water levels in pumped wells. Because wells 20BR, 15BR, 36BR, and 45BR were pumped, it is difficult to assess changes in the hydraulic gradients between wells in this section.

The potentiometric surface in section I-I' (fig. 6i) shows a downward hydraulic grad int of about $2 \mathrm{ft}$ from well 33BR to 40BR in 200). In 1999, during the drought, the gradient between these two wells was upward at about $0.5 \mathrm{ft}$. The potentiometric surface for section J-J' (fig. 6j) shows an upward hydraulic gradient in the bedrock of about $0.5 \mathrm{ft}$ between wells 58BR and 59BR, indicating potential discharge of ground water to the spring and swamp southwest of NAWC. 
FEET

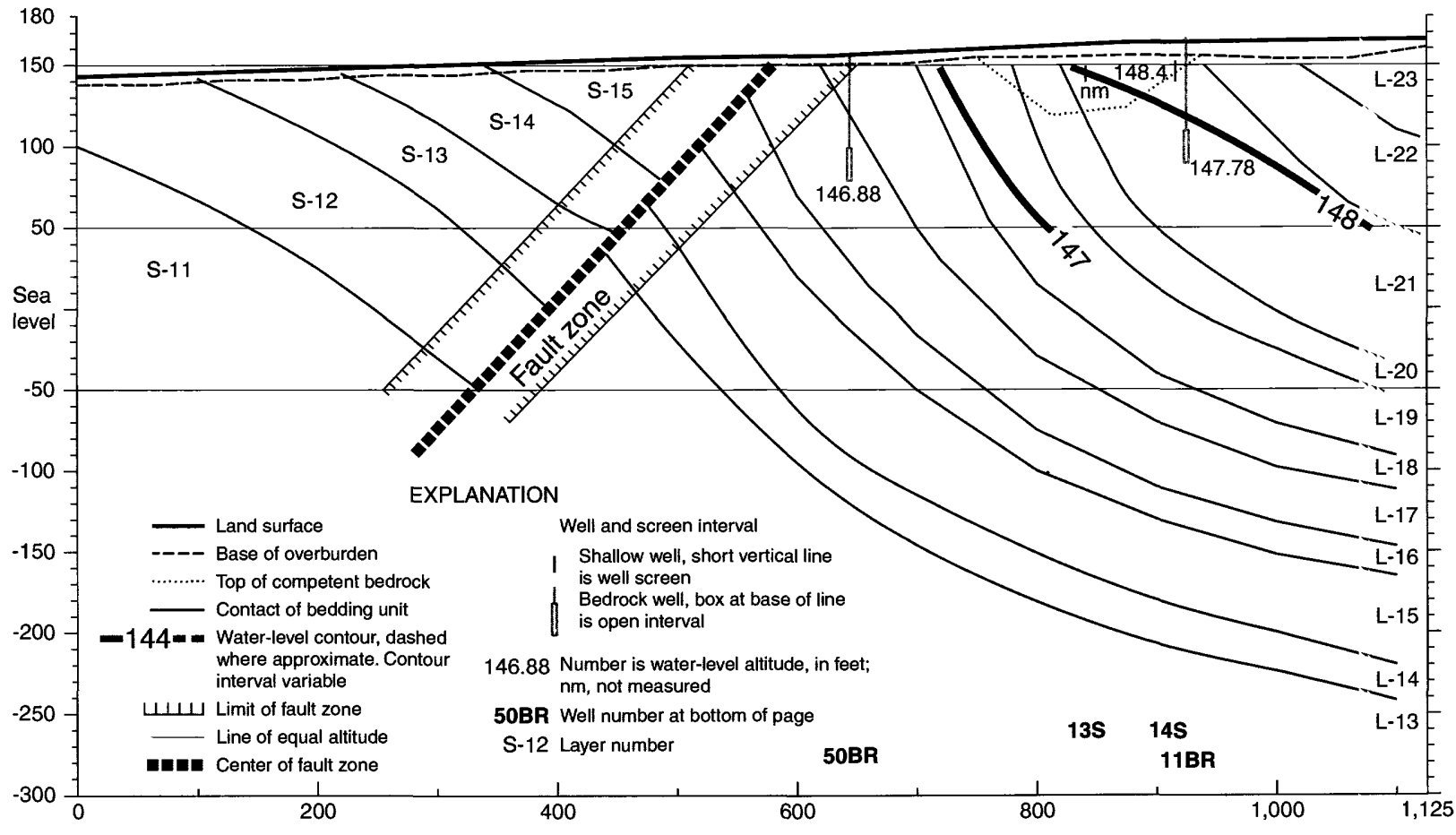

DISTANCE, IN FEET

Figure 6a. Stressed water-level altitudes and potentiometric surface along section $A-A^{\prime}$, May $18,2 ? 00$, Naval Air Warfare Center, West Trenton, N.J.

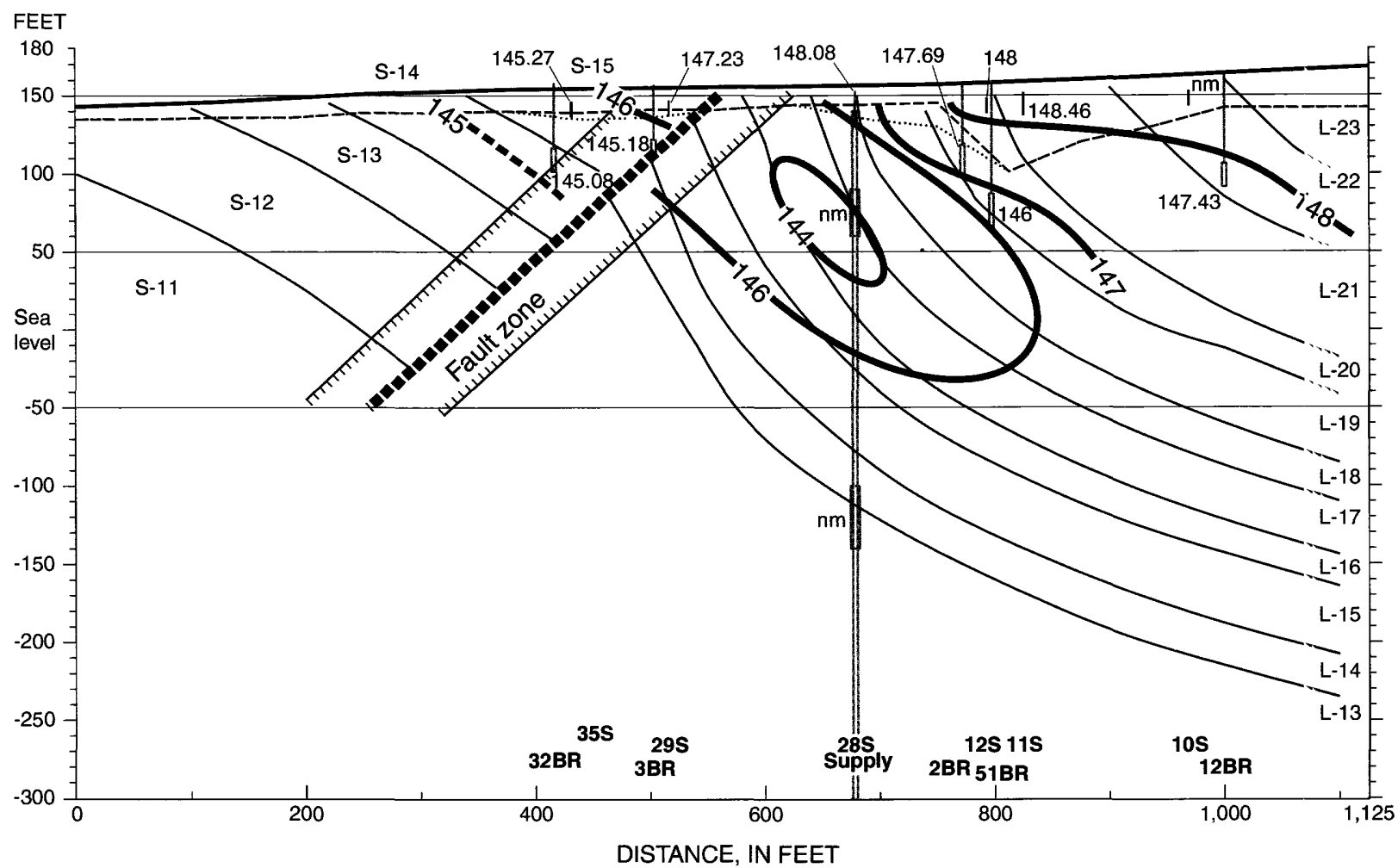

Figure 6b. Stressed water-level altitudes and potentiometric surface along section $B-B^{\prime}$, May 18,2000 , Naval Air Warfare Center, West Trenton, N.J. 


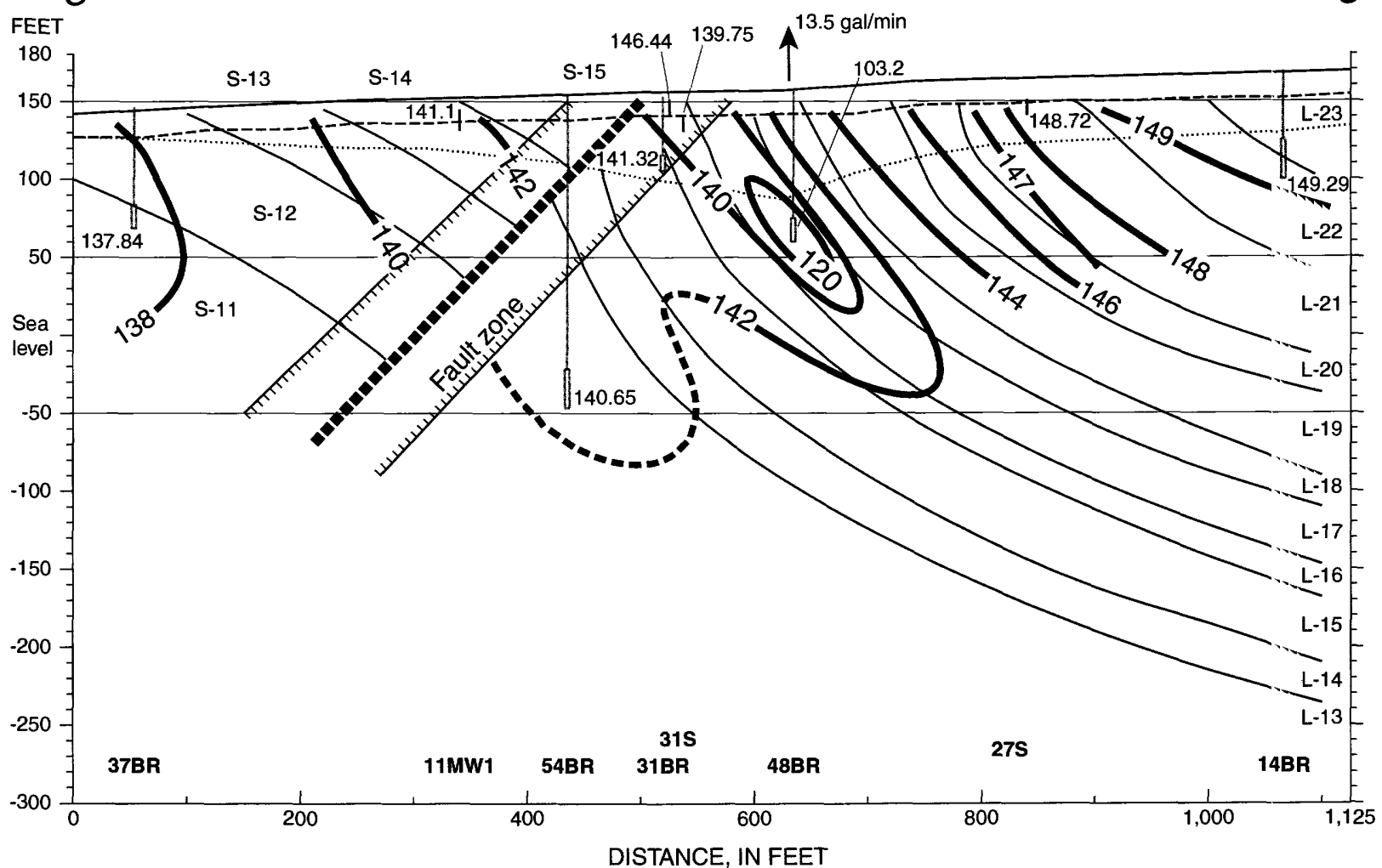

Figure 6c. Stressed water-level altitudes and potentiometric surface along section $C-C^{\prime}$, May 18,2000 , Naval Air Warfare Center, West Trenton, N.J.

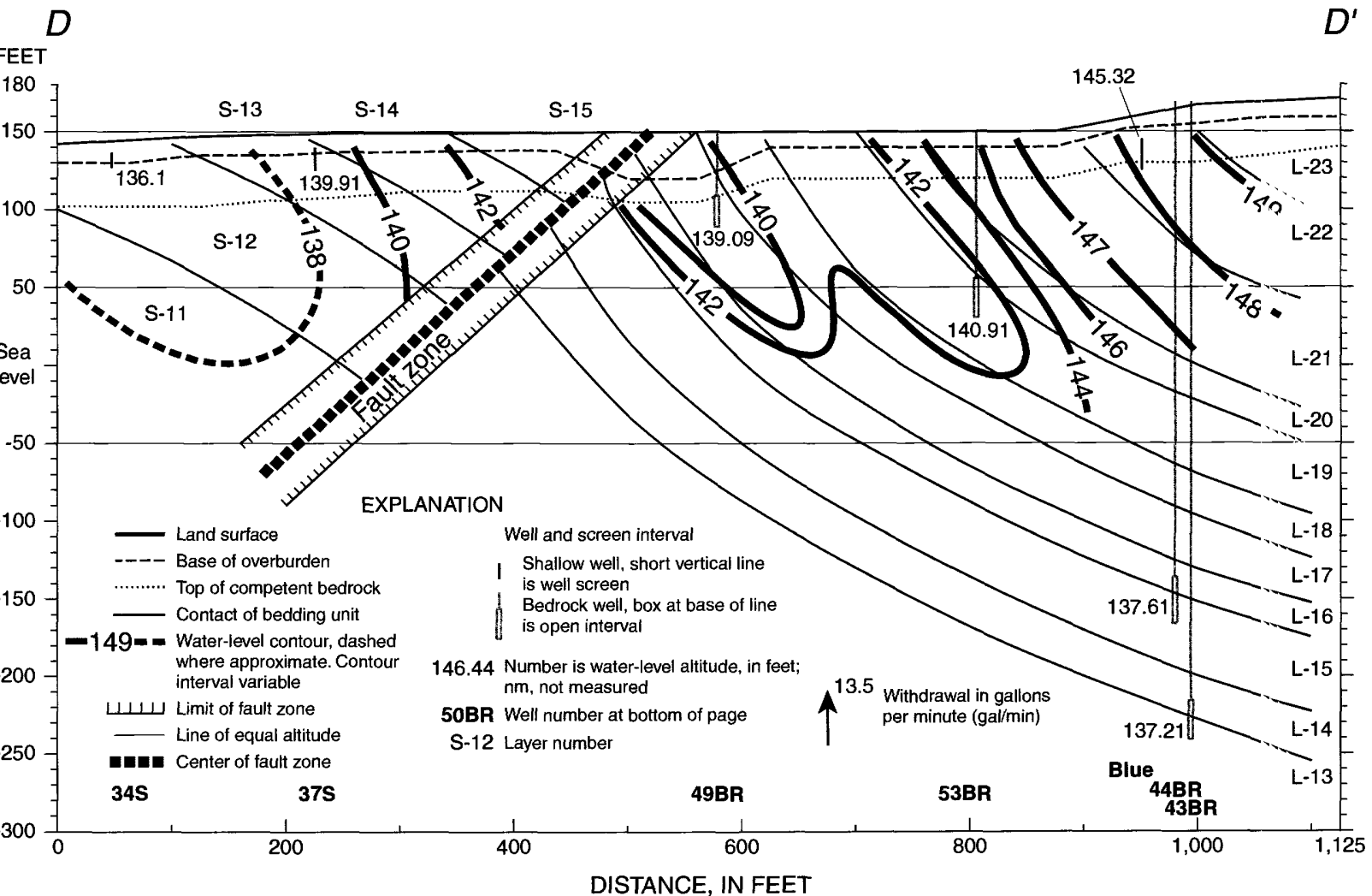

Figure 6d. Stressed water-level altitudes and potentiometric surface along section $D-D^{\prime}$, May 18, 2000, Naval Air Warfare Center, West Trenton, N.J. 
$E$

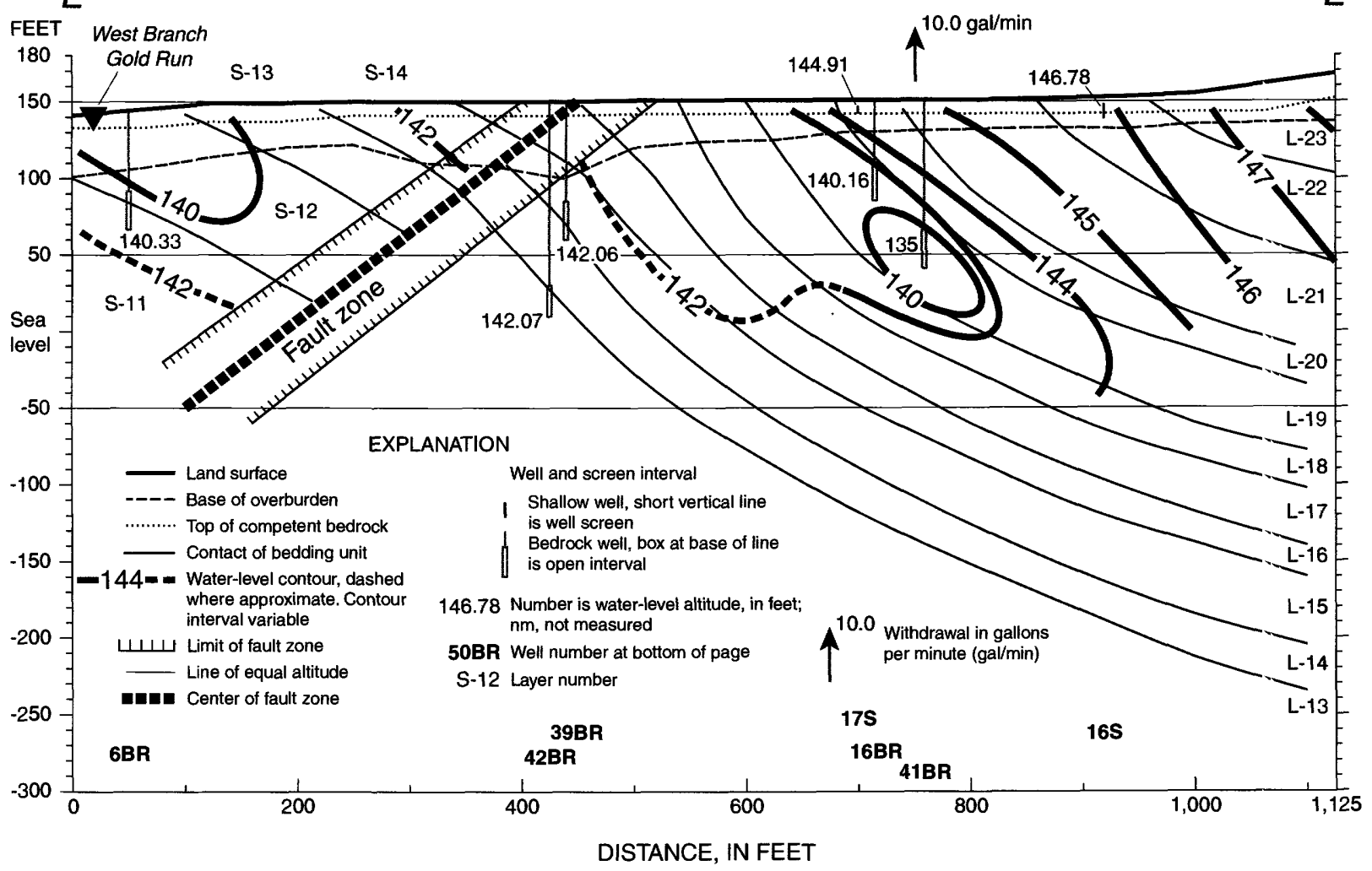

Figure 6e. Stressed water-level altitudes and potentiometric surface along section $E-E^{\prime}$, May 18,2000 , Naval Air Warfare Center, West Trenton, N.J.

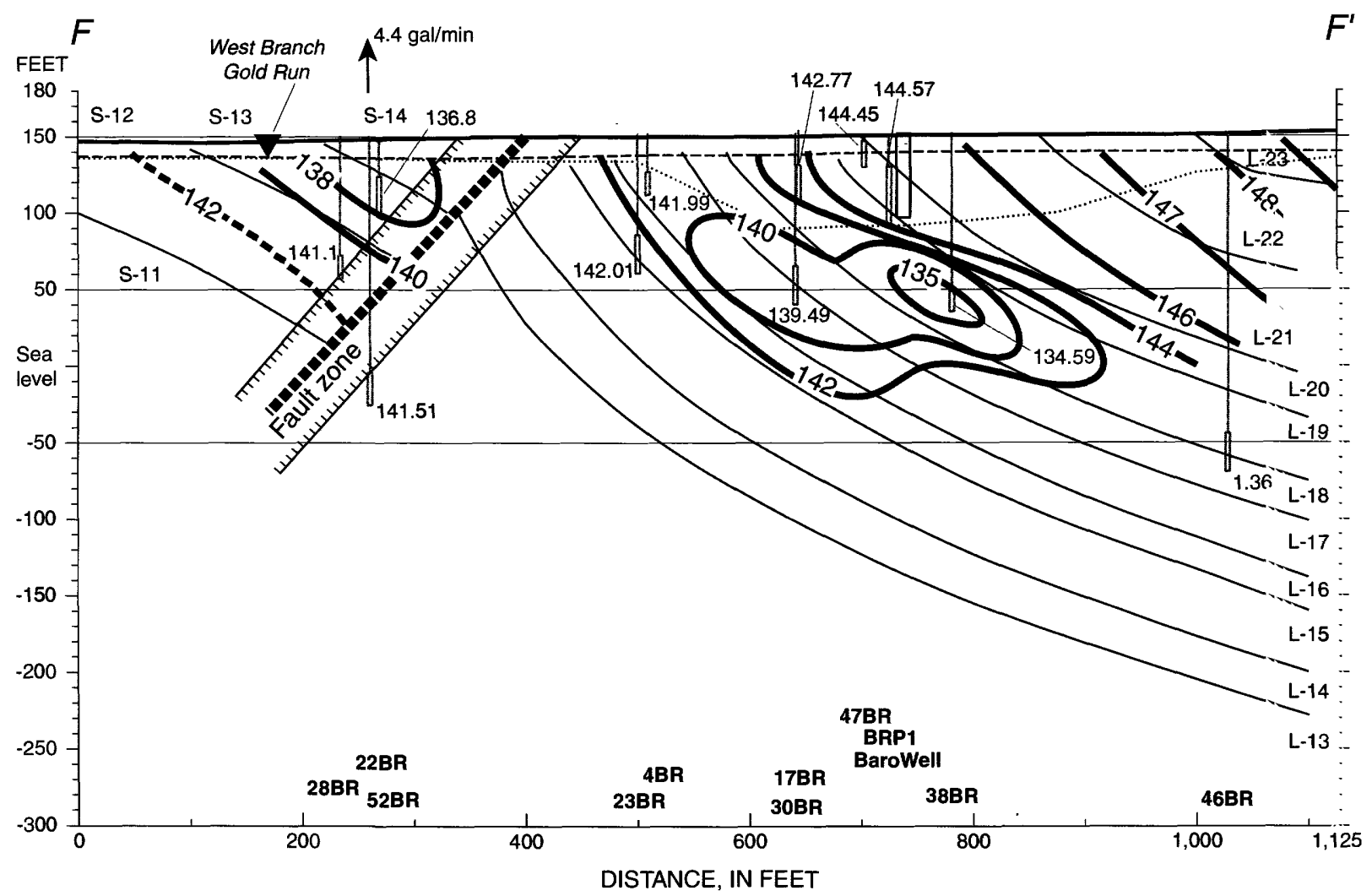

Figure 6f. Stressed water-level altitudes and potentiometric surface along section $F-F^{\prime}$, May $18,2.000$, Naval Air Warfare Center, West Trenton, N.J. 


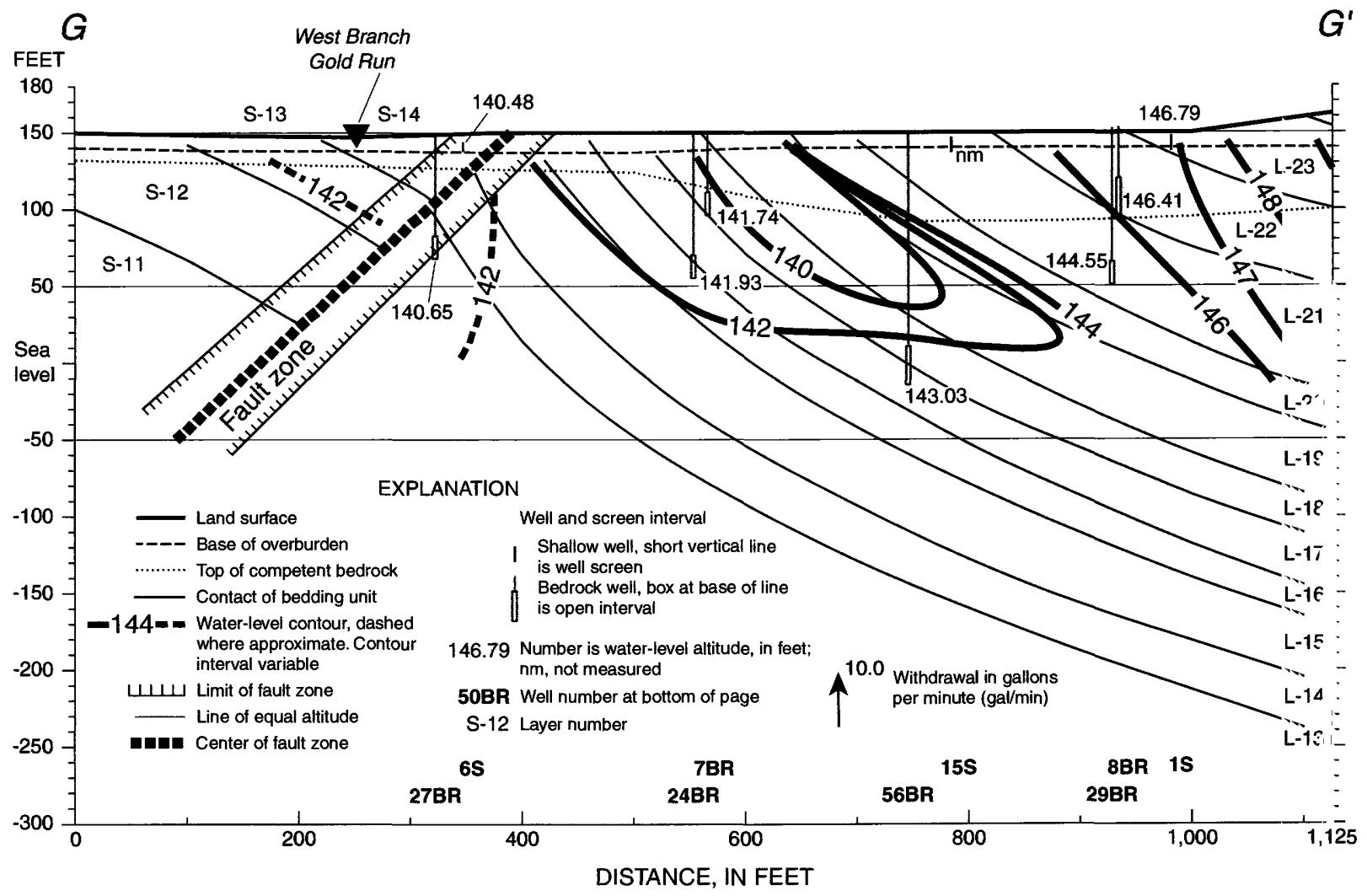

Figure 6g. Stressed water-level altitudes and potentiometric surface along section G-G', May 18, 2700, Naval Air Warfare Center, West Trenton, N.J.

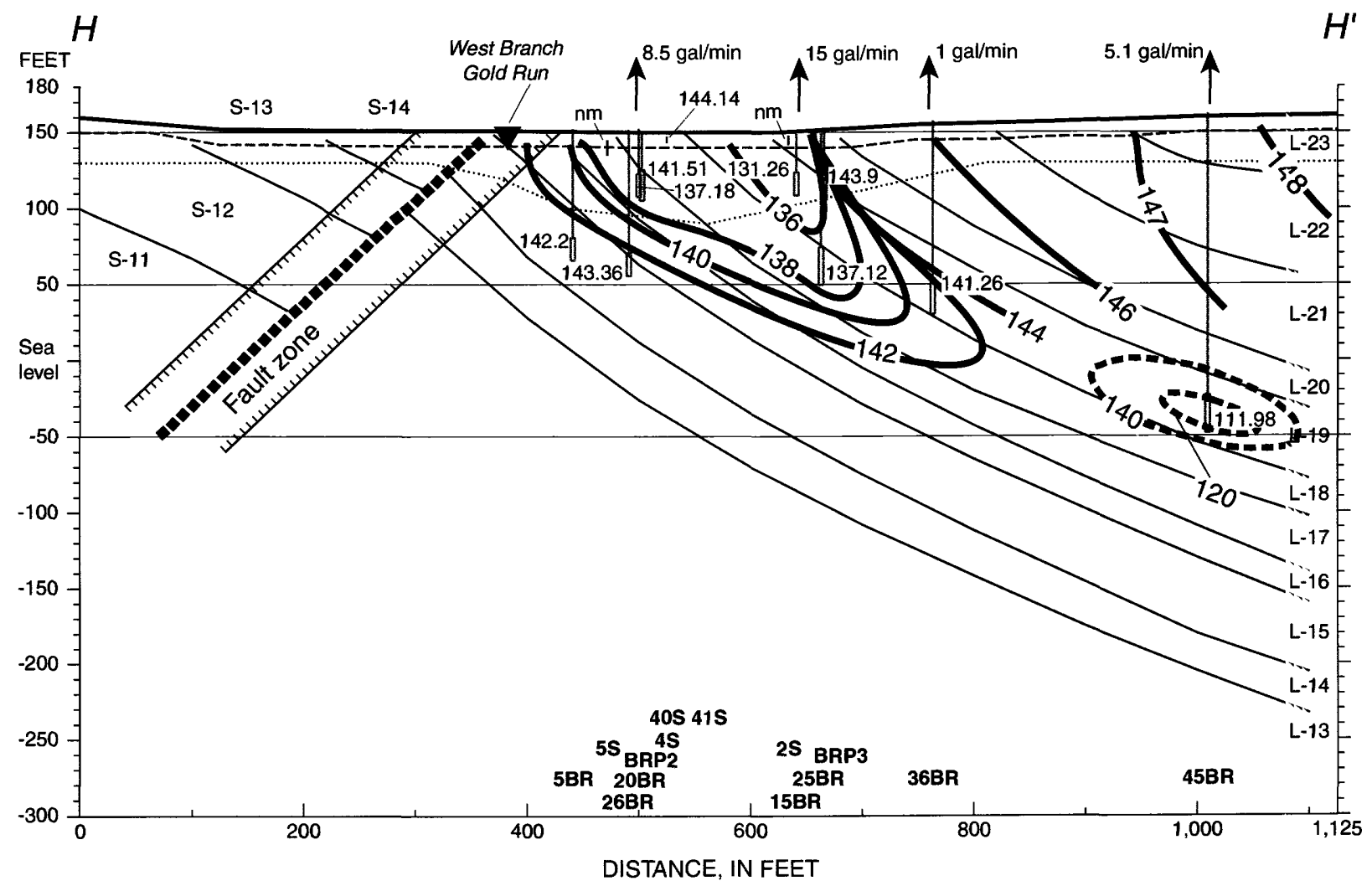

Figure $6 \mathrm{~h}$. Stressed water-level altitudes and potentiometric surface along section $H-H^{\prime}$, May 18,2000 , Naval Air Warfare Center, West Trenton, N.J. 


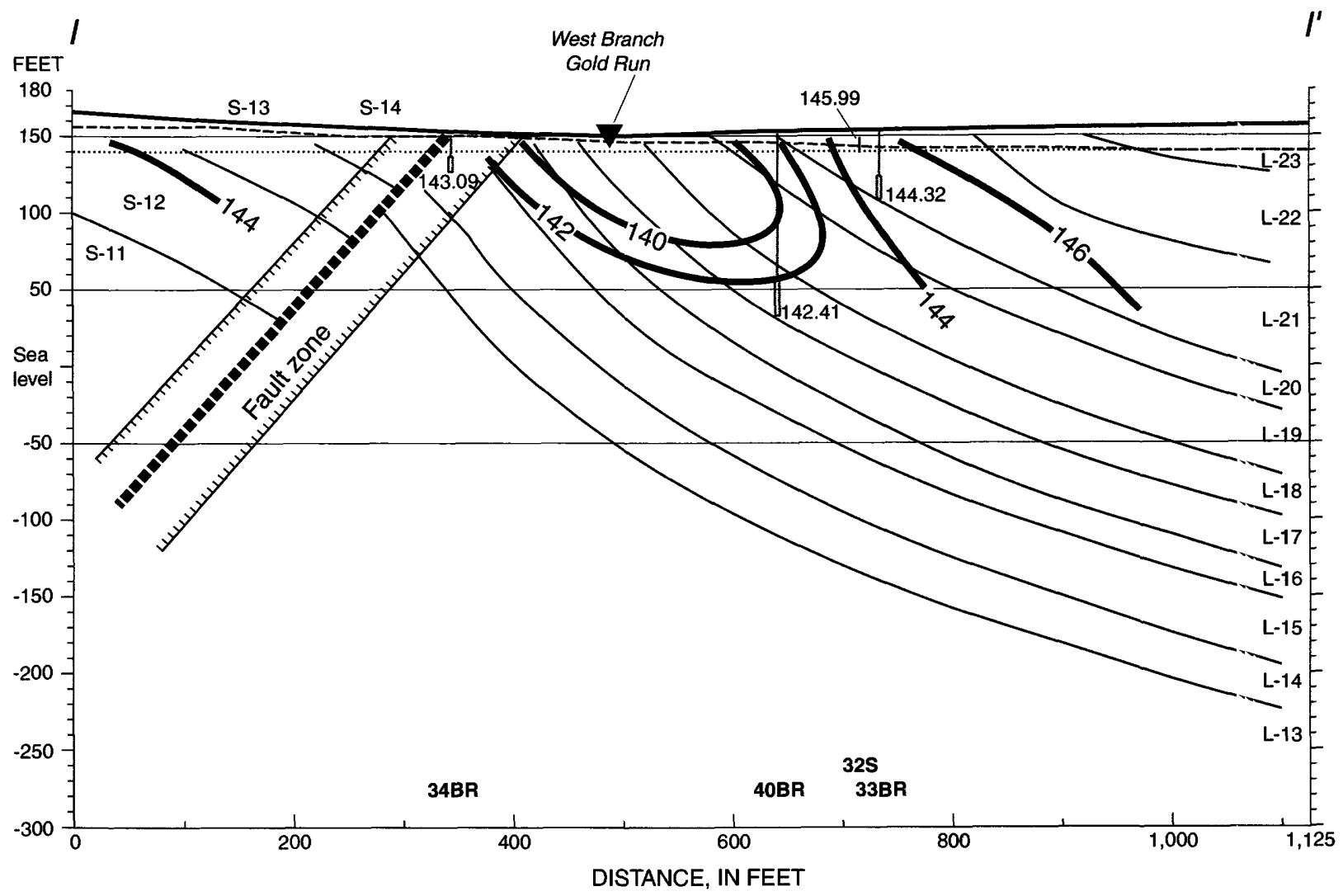

Figure 6i. Stressed water-level altitudes and potentiometric surface along section $1-1$ ', May 18, 2010, Naval Air Warfare Center, West Trenton, N.J.

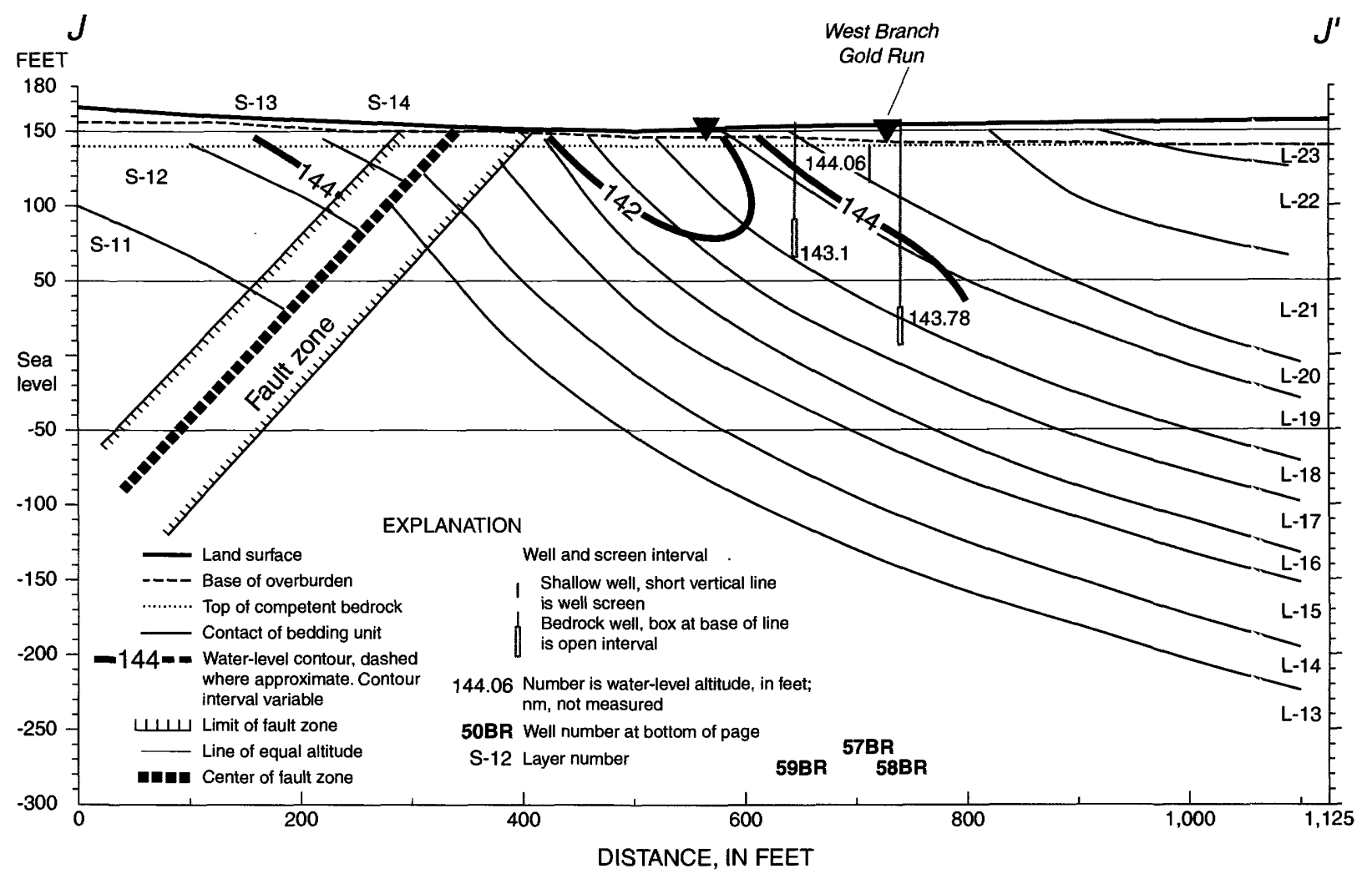

Figure 6j. Stressed water-level altitudes and potentiometric surface along section $J-J$ ', May 18, 2700, Naval Air Warfare Center, West Trenton, N.J. 


\section{Static Potentiometric Surface, October 23, 2000}

Water-level altitudes were measured on October 23, 2000, after the pumps in the six recovery wells had been turned off for 3 days. The purpose of collecting these data was to map the static potentiometric surface near Sites 1 and 3 using water levels in all of the wells at NAWC.

The water-level data were plotted in maps and sections and contoured (fig. 7 to 9). Static water-level altitudes on this date in the wells completed in bedrock ranged from $161.42 \mathrm{ft}$ in well $18 \mathrm{BR}$ on the north side of NAWC to $137.43 \mathrm{ft}$ in well 37BR on the south side of NAWC (table 1).

The static potentiometric-surface maps and sections for October 23, 2000, are similar to the static potentiometric-surface maps and sections for December 4, 1995 (Lacombe, 2000, p. 43-53), which was the last time static water levels were measured at NAWC. Water levels were measured on both dates in the same 34 bedrock wells. Water levels declined in 32 bedrock wells and rose in 2 wells (table 1). The increase in water levels in the two wells most likely is the result of measurement error. The location of the fault along sections A, B, and $\mathrm{C}$ has been modified, and now the fault is south of the location shown in December 1995. The modification resulted in a change in the shape of the potentiometric-surface contour lines at Site 3. Twenty-one bedrock wells (wells 39BR to 59BR) and four shallow wells (11-mw-1 to 35-mw2) have been installed since 1995; the additional data were used to refine the location of potentiometric-surface contours in many areas. In addition, since the formal closure of NAWC in 1998, sump pumps in the basements of many buildings have been turned off. As a result, water levels have risen near these sump pumps. In summation, many small changes were made to the shapes of the potentiometric surfaces from 1995 maps and sections to the 2000 maps and sections. As a result, it is difficult to compare the water-level data for the two dates.

The static potentiometric surface at land surface (fig. 7) shows the area north of Site 3 has the highest hydraulic head. The area with the lowest hydraulic head is the west branch of Gold Run. The contour lines are in a "V" shape around the upper reaches of Gold Run, and the long contour lines are nearly parallel to the strike of the bedrock. The contour lines near Site 3 are more oblique to the strike of the bedrock than those at Site 1.

The static potentiometric-surface contours at $100 \mathrm{ft}$ below land surface (fig. 8) are similar in shape to the contours for land surface. In December 1995, (Lacombe, 2000, fig. 29) the potentiometric surface near wells $39 \mathrm{BR}$ and $42 \mathrm{BR}$ were drawn such that static water levels appear much lower in December 1995 than in October 2000. This appearance is a result of a paucity of data in this area during 1995. A sump pump located near the southeastern part of Building 21 was active in 1995 and most likely caused ground-water levels in the area to decline. The sump pump was turned off about the same time that NAWC was decommissioned. As a result, ground-water levels near the sump pump rose, and the static potentiometric surface for October 2000 is more realistic in this area than the static surface shown for December 1995.

The static potentiometric surface for section A-A' (fig. 9a) shows a southward hydraulic gradient of less than $1 \mathrm{ft}$ between wells $11 \mathrm{BR}$ and 50BR. The hydraulic gradient in section B-B' (fig. 9b) is from well 12BR downward toward well 51BR. The hydraulic gradient between wells $2 \mathrm{BR}$ and $51 \mathrm{BR}$ is $0.04 \mathrm{ft}$, and that gradient may be insignificant. The general gradient is downward and southward. The static potentiometric surface for section C-C' (fig. 9c) shows the hydraulic gradient between wells $14 \mathrm{BR}$ and $48 \mathrm{BR}$, and between $48 \mathrm{BR}$ and $54 \mathrm{BR}$ is about 3 and $5.5 \mathrm{ft}$, respectively. The water-level altitude in well $54 \mathrm{BR}$, is $139.96 \mathrm{ft}$. This water level is 5 to $6 \mathrm{ft}$ lower than water levels in all the wells that are around it. The reason for the high gradient around this well is unclear. The hydraulic gradient between wells 53BR and 49BR on section D-D' (fig. 9d) is upward and eastward. Because wells $43 \mathrm{BR}$ and 44BR have such a low hydraulic conductivity, the 2000 water levels probably are not stabilized. The hydraulic gradient at Site 3 (sections $\mathrm{A}, \mathrm{B}, \mathrm{C}$, and $\mathrm{D}$ ) is downward near well $12 \mathrm{BR}$ and southwesterly in other areas.

The potentiometric surface along section E-E' (fig. 9e) shows a downward hydraulic gradi- 


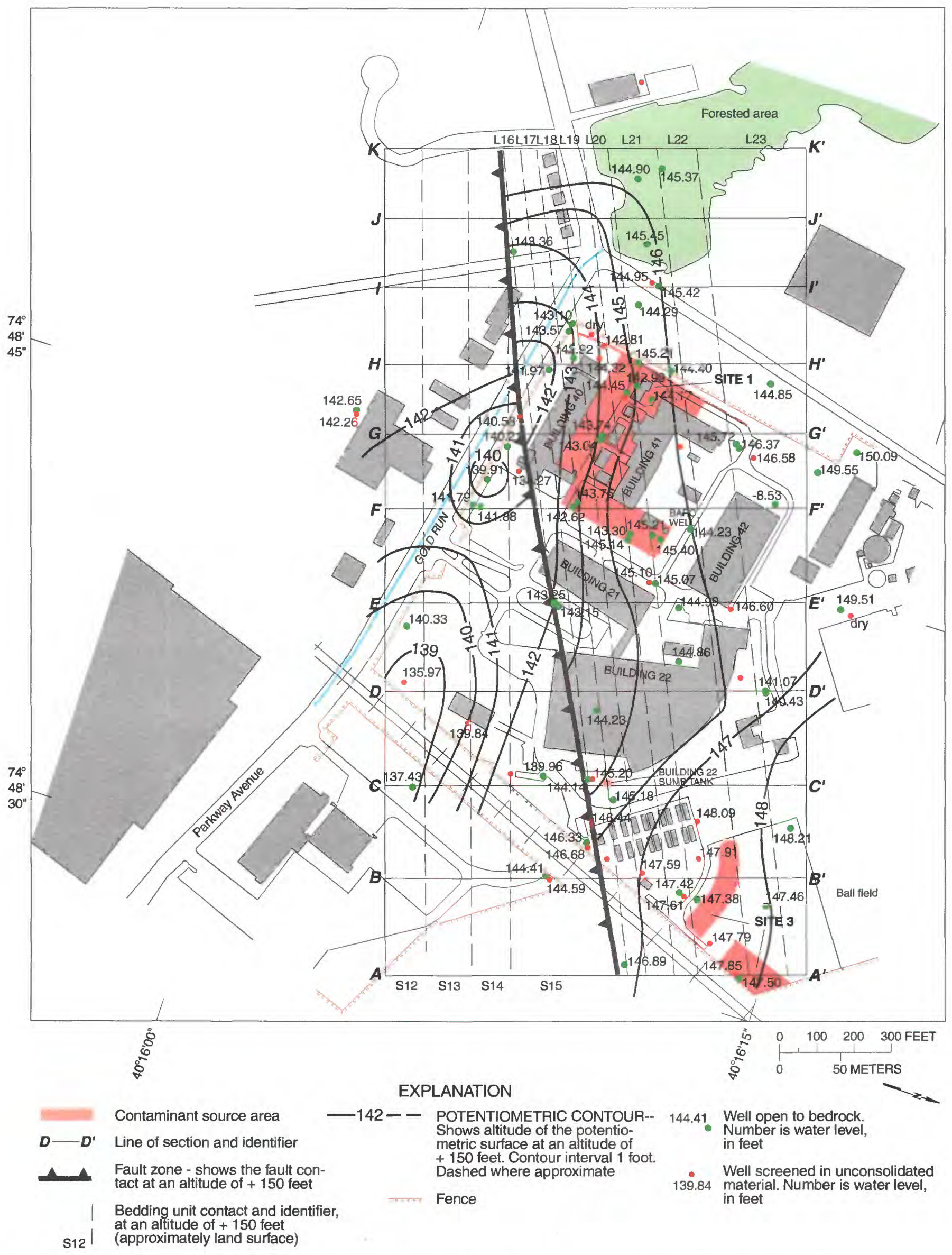

Figure 7. The static potentiometric surface at an altitude of +150 feet (approximately land surface), October 23, 2000, Naval Air Warfare Center, West Trenton, N.J. 


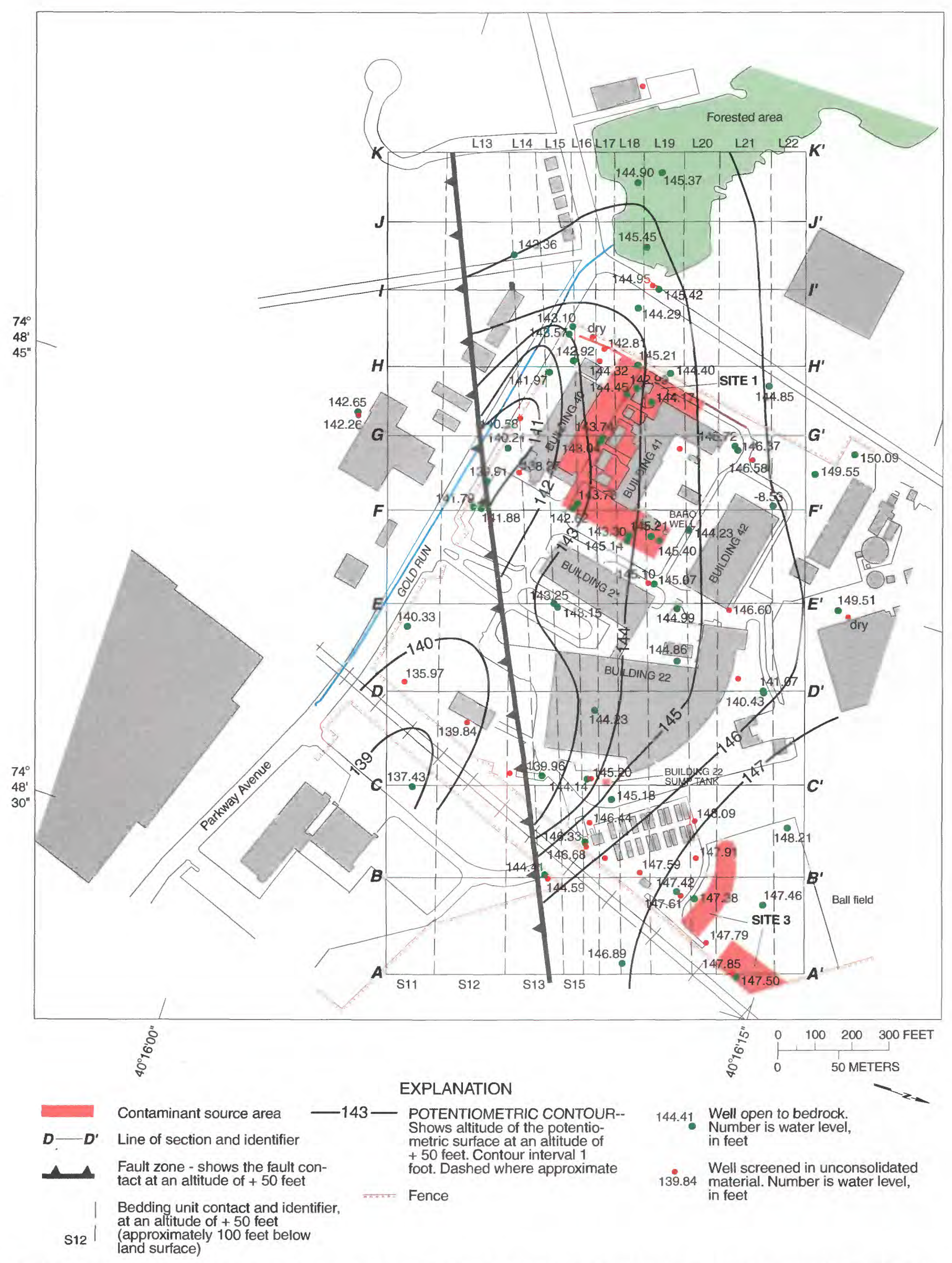

Figure 8. The static potentiometric surface at an altitude of +50 feet (approximately 100 feet below land surface), October 23, 2000, Naval Air Warfare Center, West Trenton, N.J. 


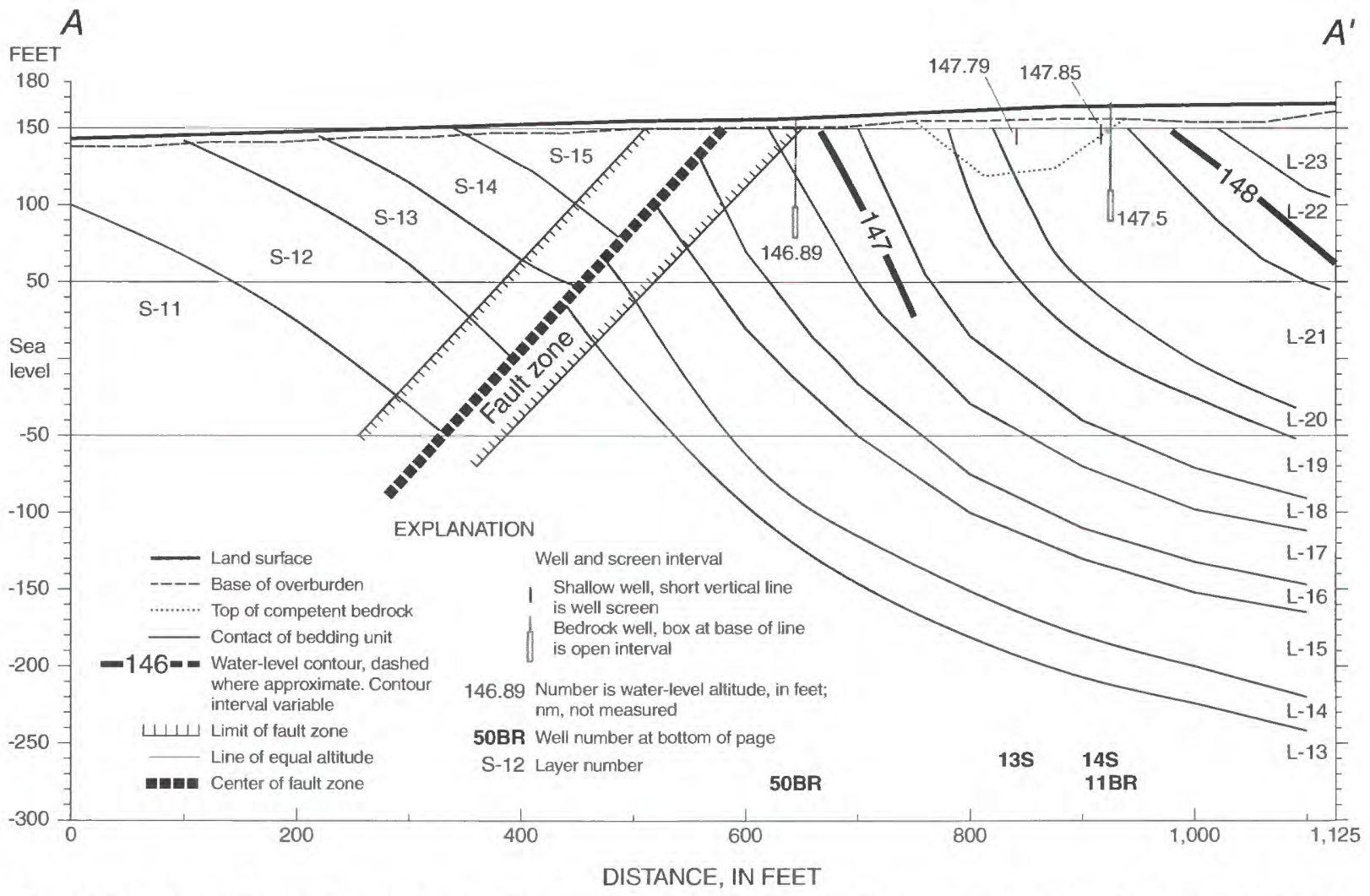

Figure 9a. Static water-level altitudes and potentiometric surface along section $A-A^{\prime}$, October 23, 2000, Naval Air Warfare Center, West Trenton, N.J.

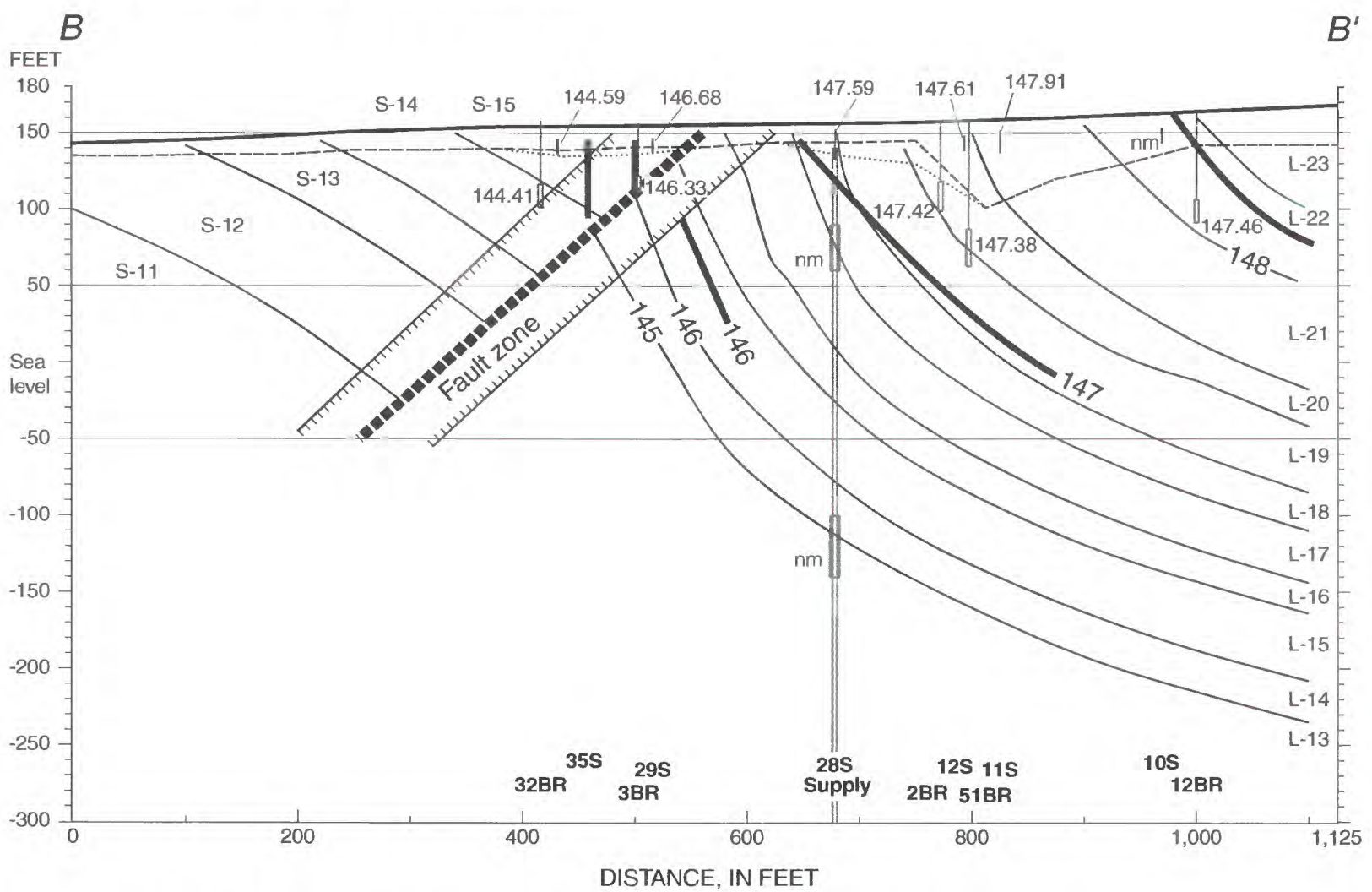

Figure 9b. Static water-level altitudes and potentiometric surface along section $B$ - $B$ ', October 23, 2000, Naval Air Warfare Center, West Trenton, N.J. 


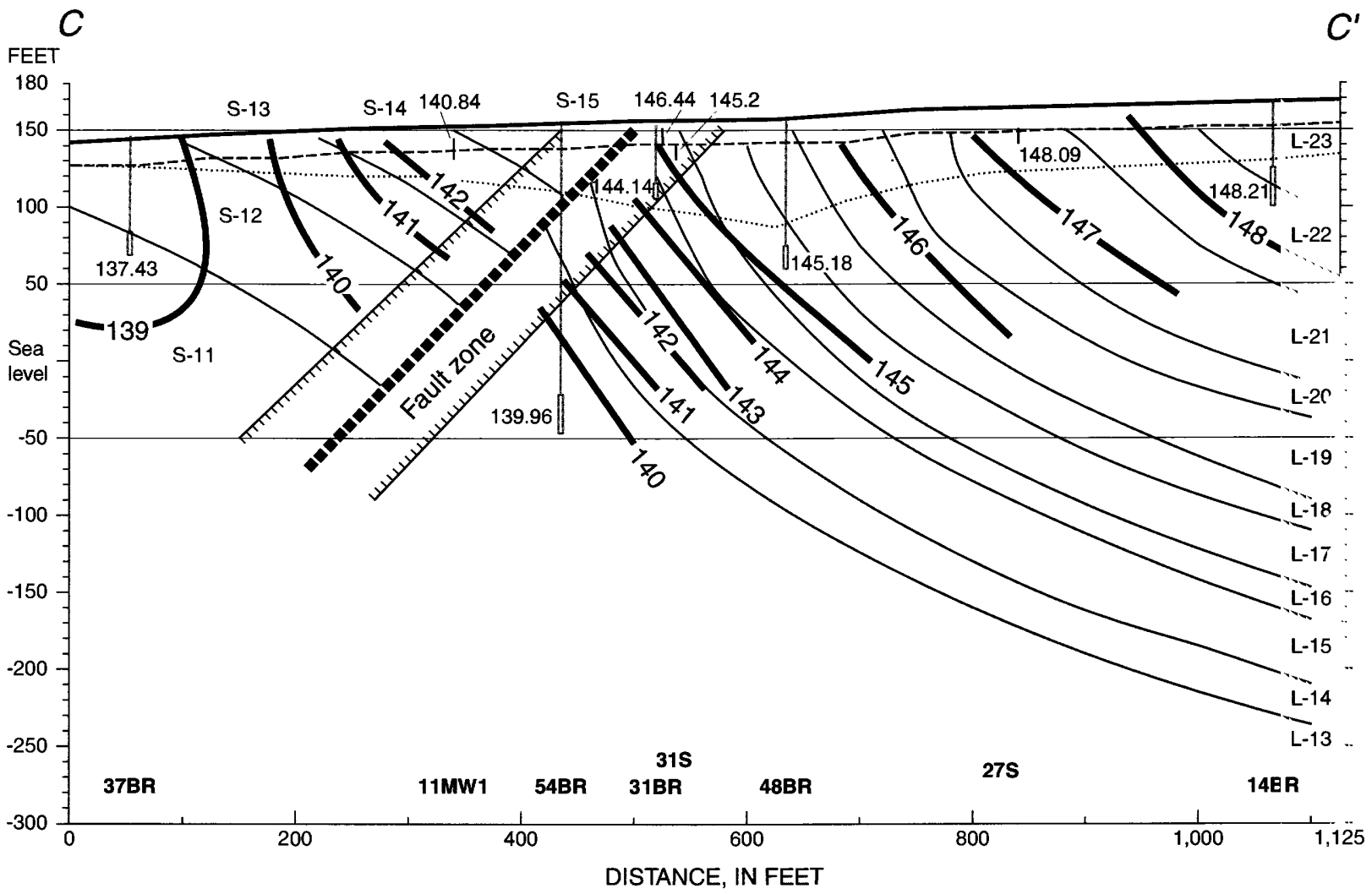

Figure 9c. Static water-level altitudes and potentiometric surface along section $C-C^{\prime}$, October 23, 2000, Naval Air Warfare Center, West Trenton, N.J.

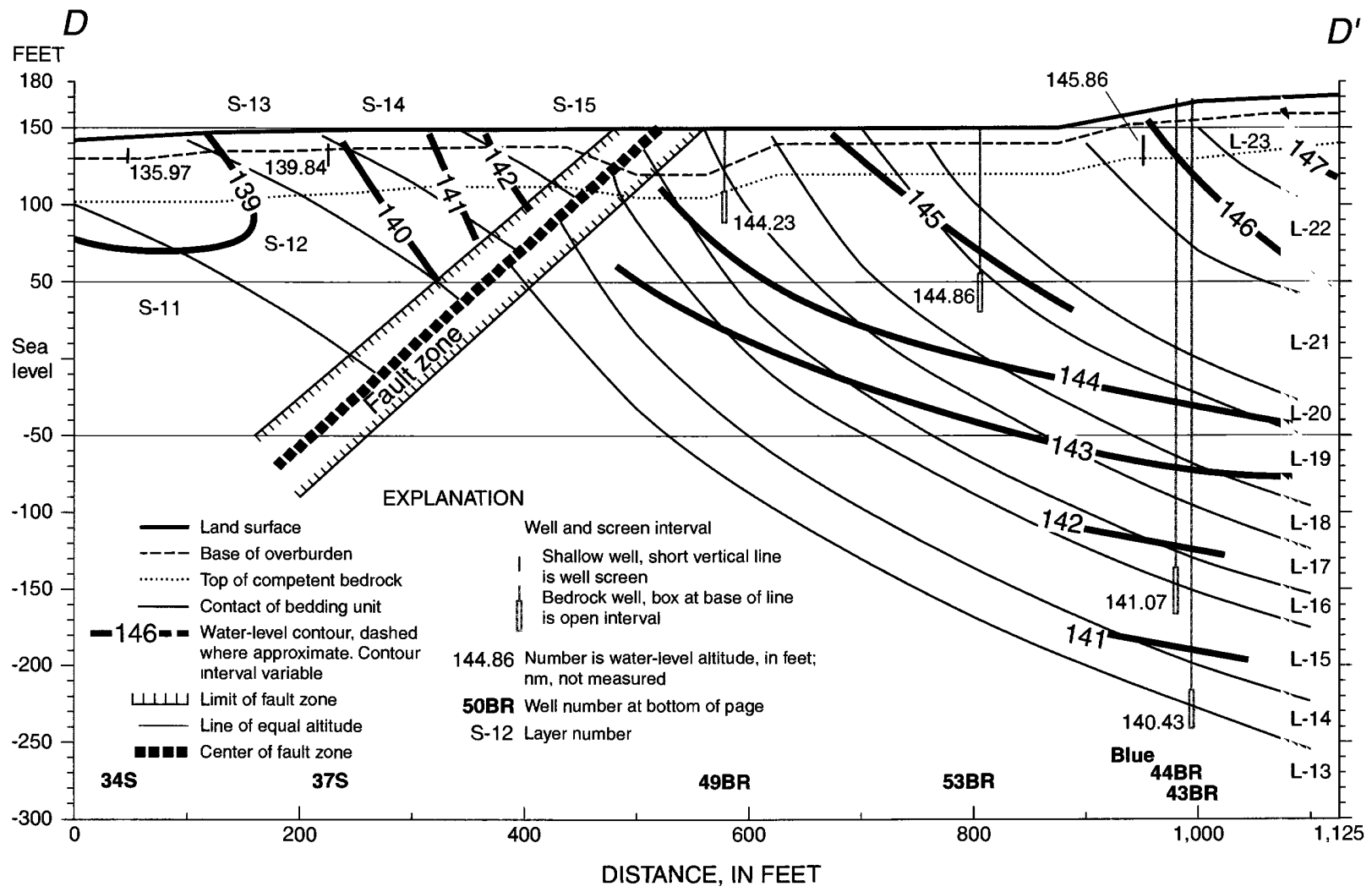

Figure 9d. Static water-level altitudes and potentiometric surface along section $D-D^{\prime}$, October 23, 2000 , Naval Air Warfare Center, West Trenton, N.J. 


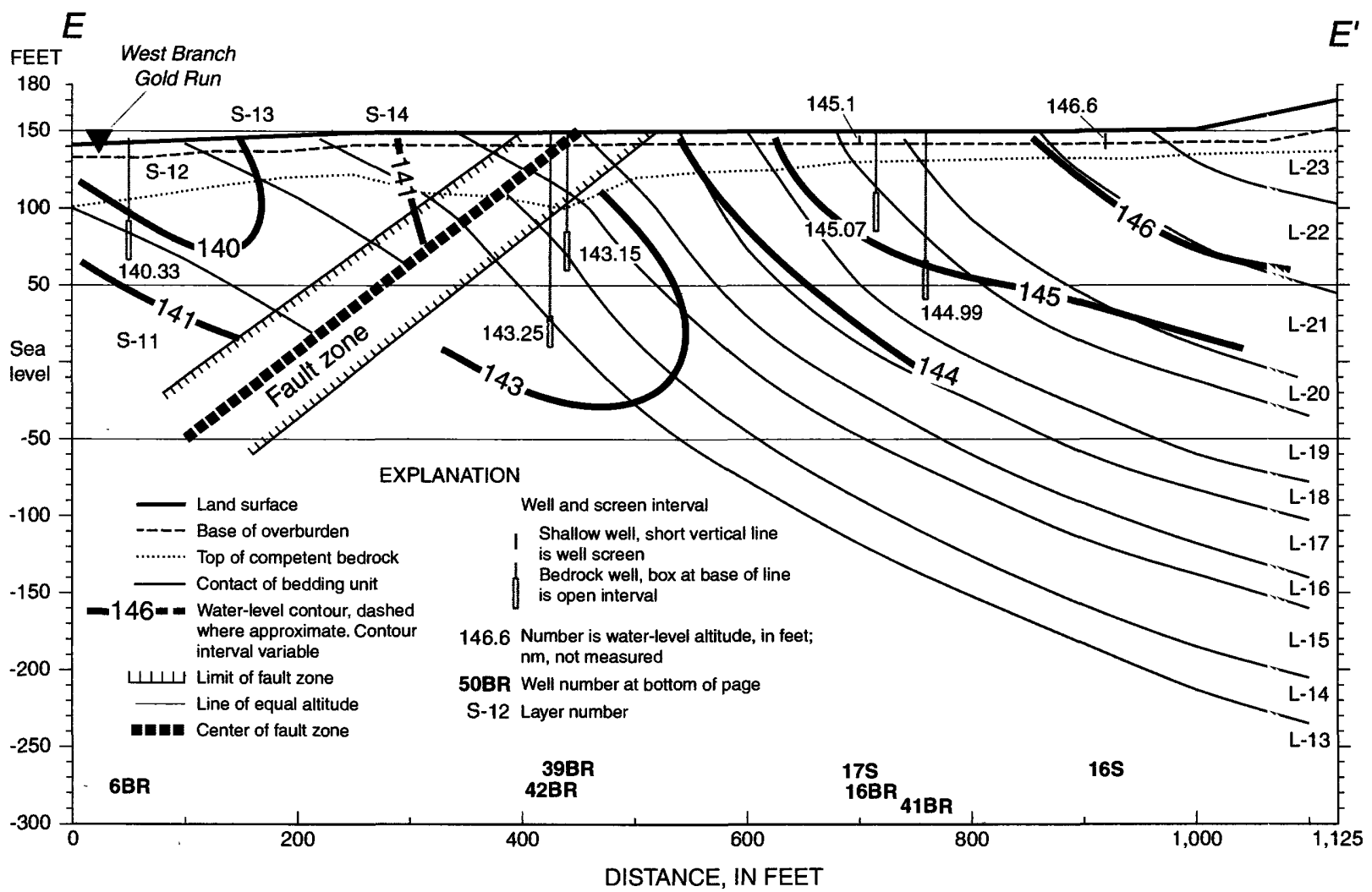

Figure 9e. Static water-level altitudes and potentiometric surface along section $E-E^{\prime}$, October 23, 2000, Naval Air Warfare Center, West Trenton, N.J.

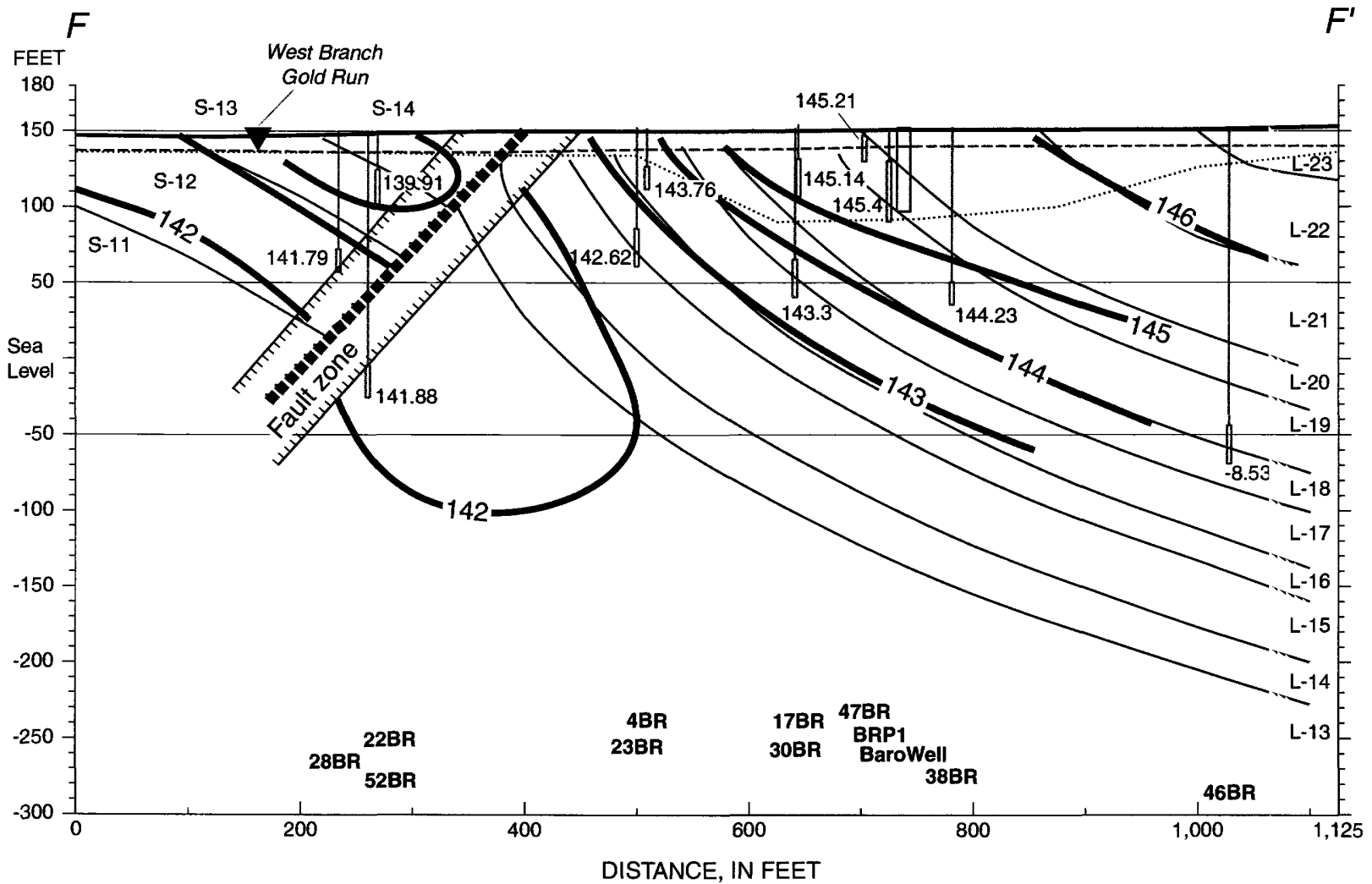

Figure 9f. Static water-level altitudes and potentiometric surface along section $F-F^{\prime}$, October 23, 2000, Naval Air Warfare Center, West Trenton, N.J. 


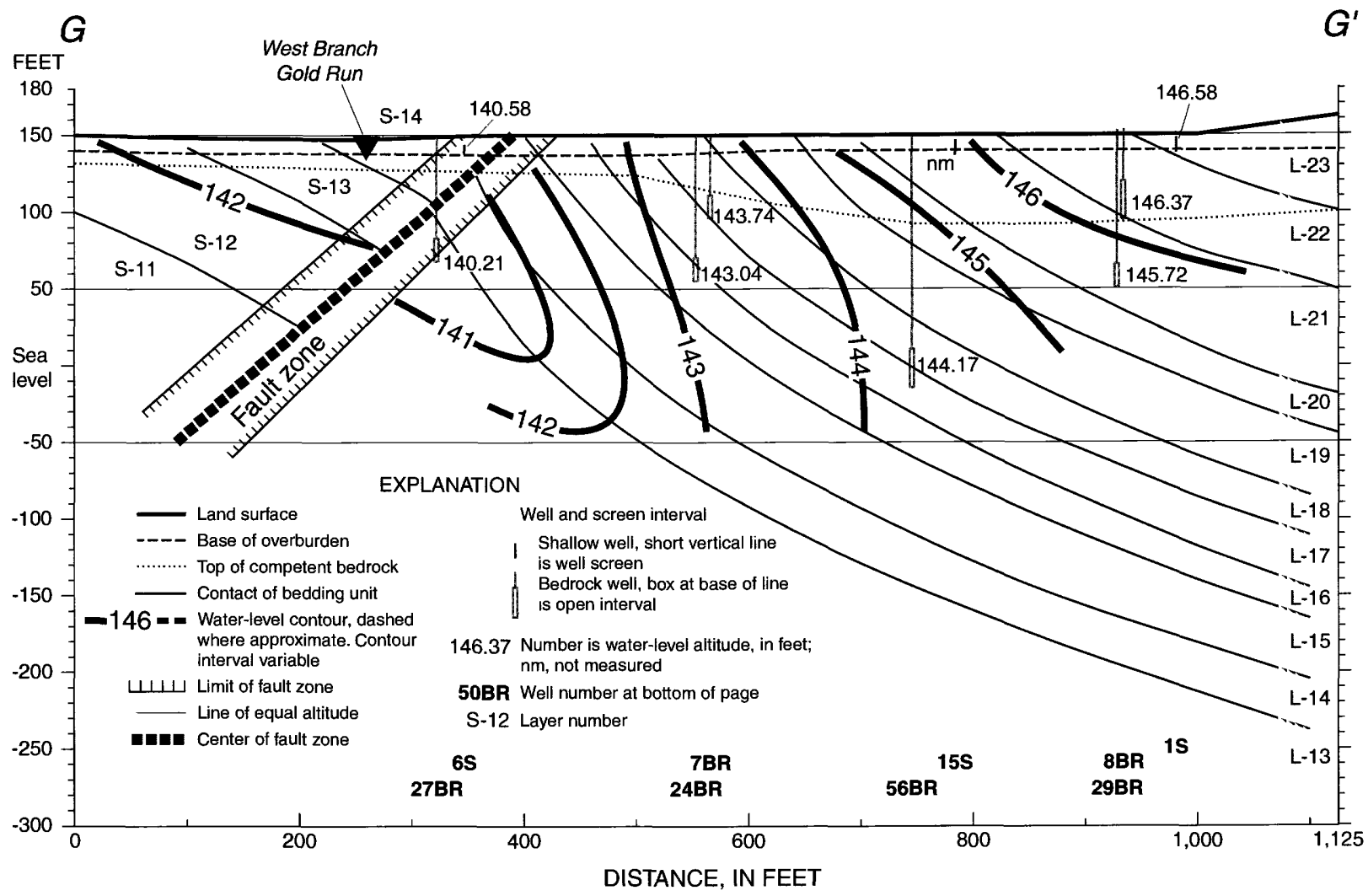

Figure 9g. Static water-level altitudes and potentiometric surface along section G-G', October 23, 2000, Naval Air Warfare Center, West Trenton, N.J.

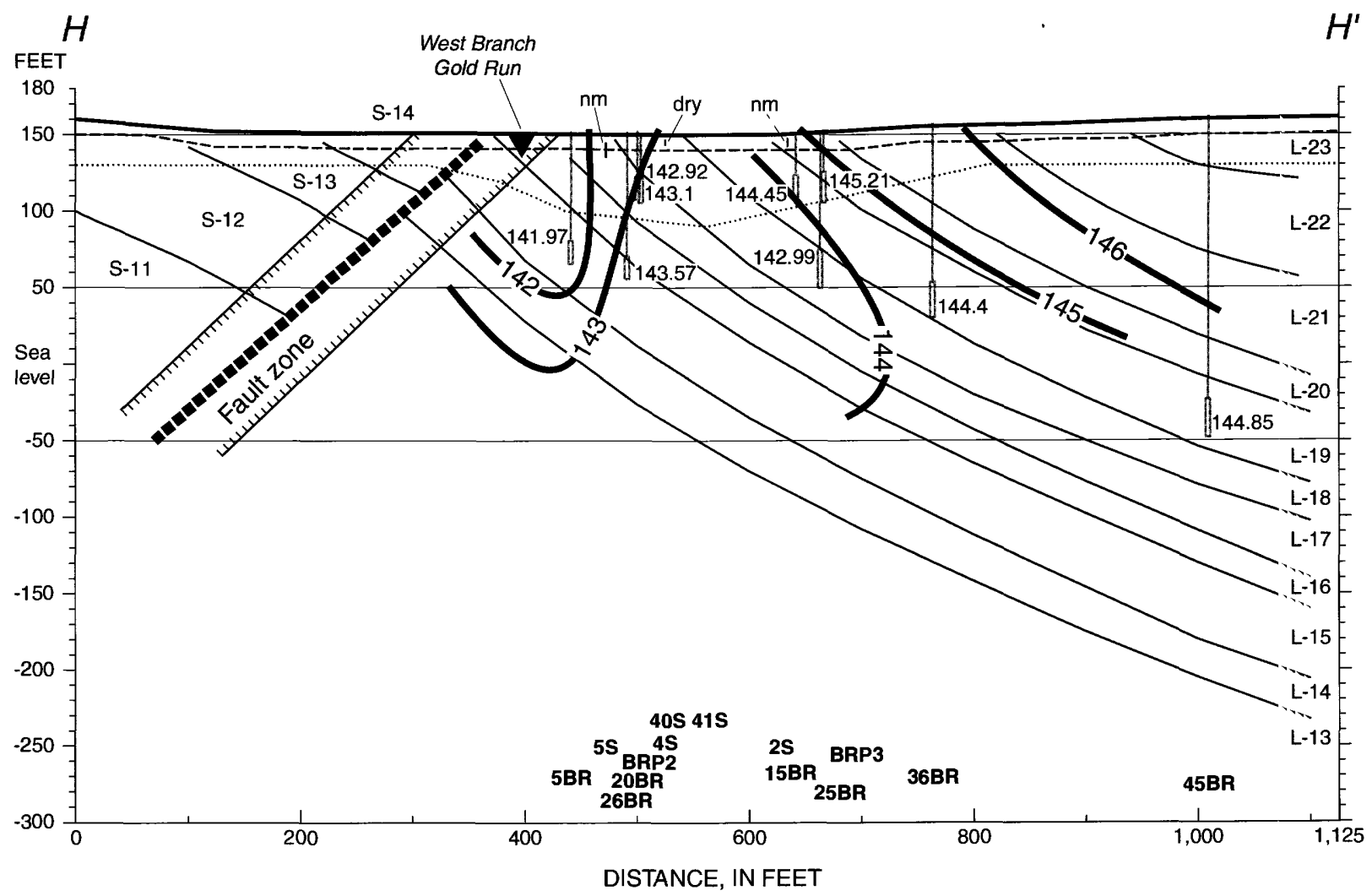

Figure 9h. Static water-level altitudes and potentiometric surface along section $H-H^{\prime}$, October 23, 2000 , Naval Air Warfare Center, West Trenton, N.J. 


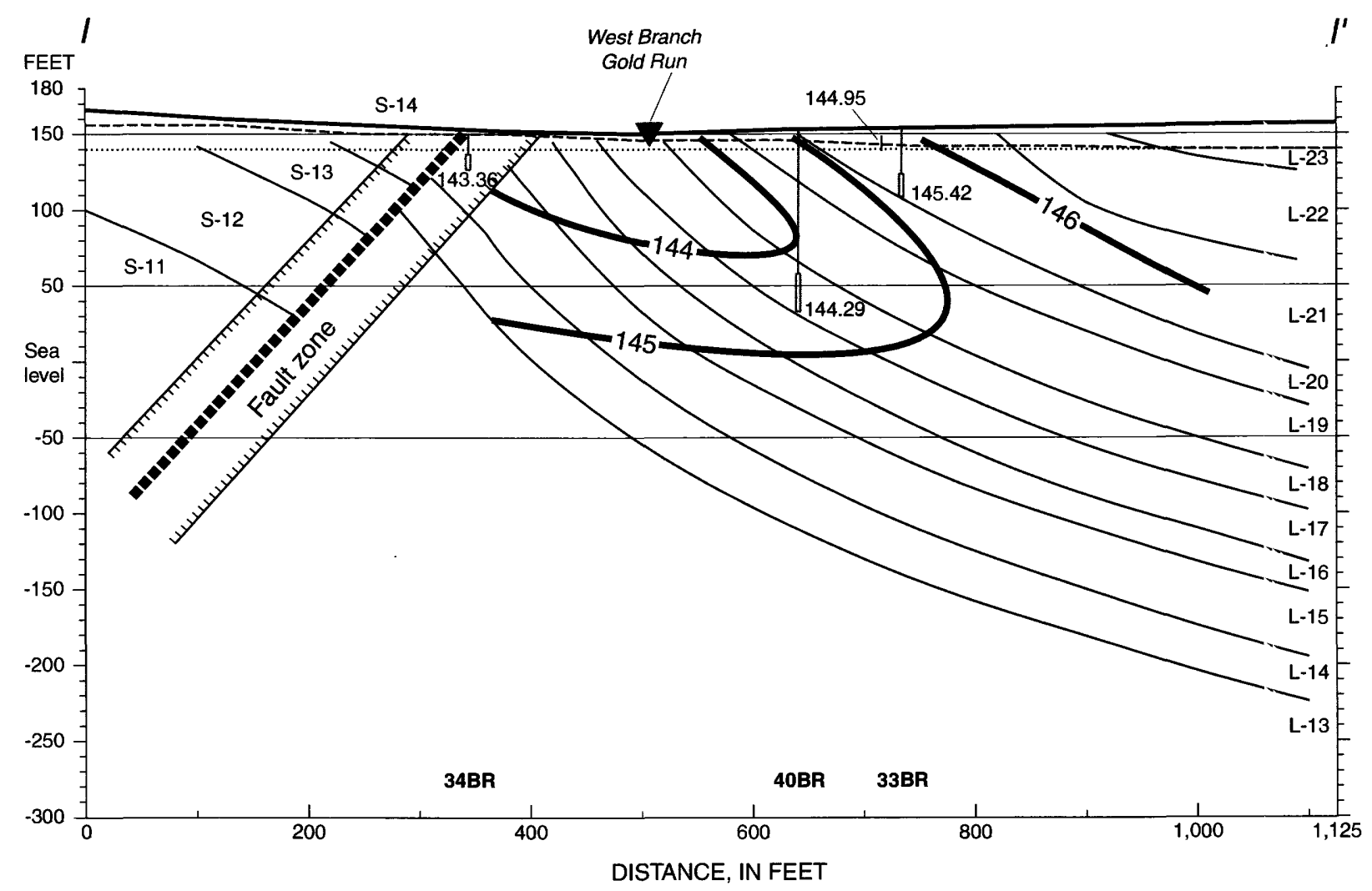

Figure 9i. Static water-level altitudes and potentiometric surface along section $I-l$, , October 23, 2000, Naval Air Warfare Center, West Trenton, N.J.

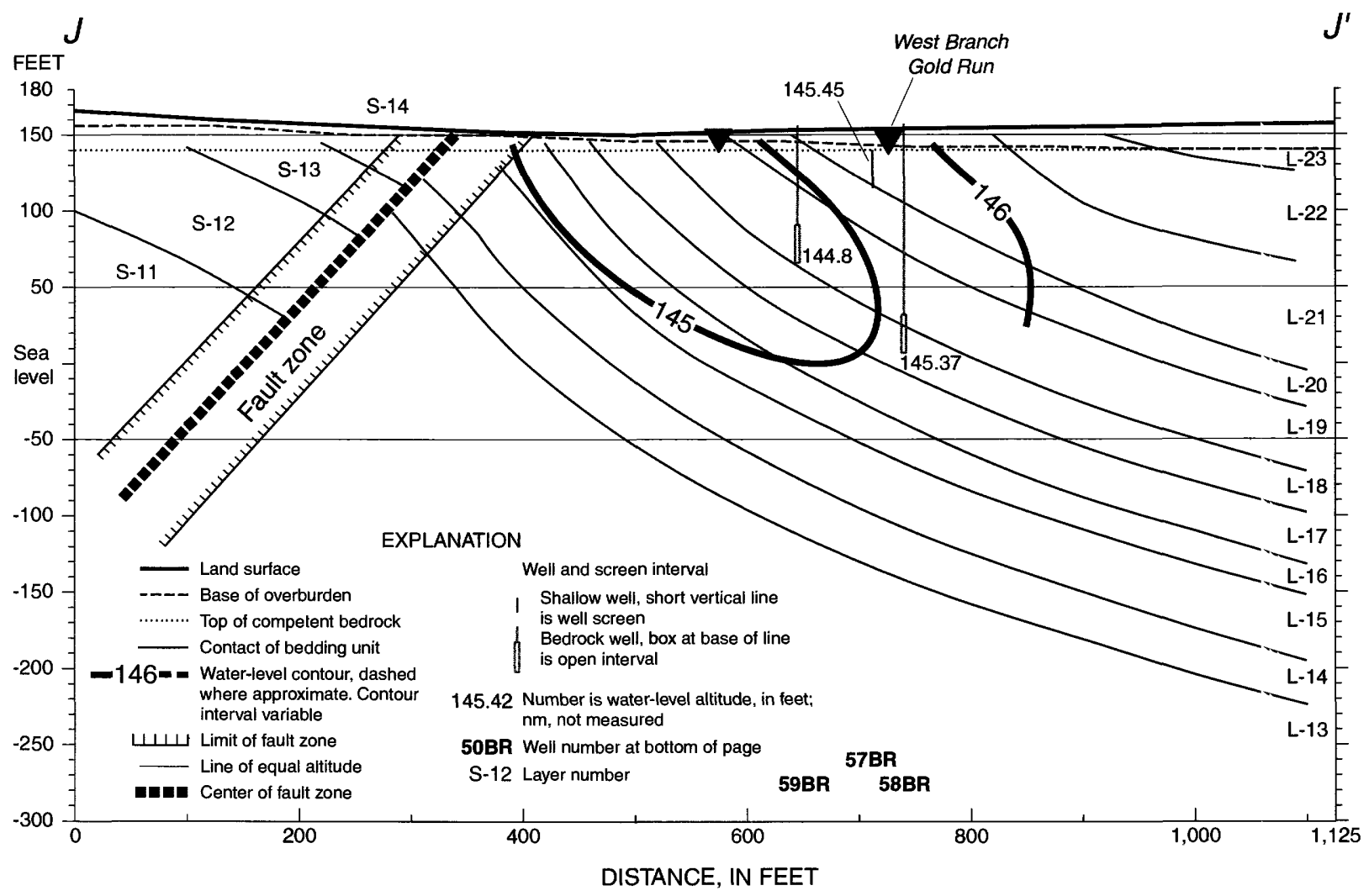

Figure 9j. Static water-level altitudes and potentiometric surface along section $\mathrm{J}-J$ ', October 23, ع.,00, Naval Air Warfare Center, West Trenton, N.J. 
ent of about $0.1 \mathrm{ft}$ between wells 16BR and 41BR and an upward hydraulic gradient of about $0.1 \mathrm{ft}$ between wells 42BR and 39BR. The 143-ft contour line is drawn to encompass wells $42 \mathrm{BR}$ and $39 \mathrm{BR}$ because of the upward hydraulic gradient between the wells. The potentiometric surface along section F-F' (fig. 9f) indicates that the general hydraulic gradient is downward and southward. The upward hydraulic gradient from well 52BR to wells $28 \mathrm{BR}$ and 22BR (fig. 9f) probably is impeded by the fault that acts as a confining unit. The 142-contour line, however, is drawn to show an upward hydraulic gradient much like that shown in sections E-E', G-G', and $\mathrm{H}-\mathrm{H}^{\prime}$. The water-level altitude in well $46 \mathrm{BR}$ is $-8.53 \mathrm{ft}$. This well has an exceptionally slow recovery rate, and the anomalously low water level reflects the slow recovery after pumping for water-quality sampling in March 2000. The potentiometric surface for section G-G' (fig. 9g) shows a downward hydraulic gradient from well $8 \mathrm{BR}$ to well $29 \mathrm{BR}$ and well $7 \mathrm{BR}$ to well $24 \mathrm{BR}$. In addition, the potentiometric-surface sections show an updip hydraulic gradient from well 56BR toward wells $7 \mathrm{BR}$ and $24 \mathrm{BR}$. Thus, the contour lines are drawn to show that ground water discharges upward toward the west branch of Gold Run. The potentiometric surface for section $\mathrm{H}-\mathrm{H}^{\prime}$ (fig. 9h) shows a downward hydraulic gradient of about $1.5 \mathrm{ft}$ between wells 25BR and 15BR and an upward hydraulic gradient of about $1.5 \mathrm{ft}$ between wells $26 \mathrm{BR}$ and $5 \mathrm{BR}$ near the west branch of Gold Run. Thus, the section shows potential discharge of ground water to Gold Run. In addition, the updip hydraulic gradient of about $1.5 \mathrm{ft}$ between wells $36 \mathrm{BR}$ and $15 \mathrm{BR}$ supports the interpretation that ground water discharges to Gold Run. The potentiometric surface section I-I' (fig. 9i) shows a downward hydraulic gradient from well 33BR to well 40BR, but the contour lines are drawn to show an upward hydraulic gradient toward Gold Run. The potentiometric surface in section J-J' (fig. 9j) shows an upward hydraulic gradient of about $0.5 \mathrm{ft}$. from well 58BR to well 59BR. The contour lines are drawn to show potential ground-water discharge to Gold Run.

\section{Change in Water Levels, May 18 to October 23, 2000}

The changes in water levels from May 18 , 2000 , when the six recovery wells were operating, to October 23, 2000, when the recovery wells were not operating, were calculated to determine the extent of the zone of influence caused by pumping the recovery wells. The changes in water levels were plotted on maps and sections and contoured (figs. 10-12). Water levels were measured on both dates in 60 bedrock wells; water levels rose in 46 wells, fell in 13 wells, and remained constant in 1 well (table 1). The greatest rises in water levels in the bedrock wells typically occurred in the pumped wells, and in these wells, water-level changes ranged from 3.11 to $41.98 \mathrm{ft}$. Wells 16BR, 25BR, 30BR, 38BR, 49BR, and $53 \mathrm{BR}$ were not pumped. Water-level increases in these wells ranged from 3.81 to $9.64 \mathrm{ft}$. These wells are close to, and are greatly affected by, nearby pumped wells. Water levels declined or remained the same in all bedrock wells south of the fault except in pumped well 22BR and nearby well 28BR. Water levels declined more than $1.0 \mathrm{ft}$ in wells $10 \mathrm{BR}$ and $14 \mathrm{BR}$, which are open to the in bedrock north of the fault but are far from the recovery wells. Water levels in well 46BR, which has a low hydraulic conductivity, did not respond quickly to changes in climate and pumping. The declines in three bedrock wells at Site 1 and Site 3 ranged from 0.04 to $0.27 \mathrm{ft}$. These wells have low hydraulic conductivities, and the water levels are known to respond slowly to recovery.

The change-in-water-level maps for Sites 1 and 3 are shown in figures 10 and 11 . Water levels rose in the area inside of the 0 - $\mathrm{ft}$ contour line. The areas with the greatest rise are associated with pumping of wells $15 \mathrm{BR}, \mathrm{BRP} 1,41 \mathrm{BR}$ at Site 1 and $48 \mathrm{BR}$ southwest of Site 3. The change-in-waterlevel sections A-A' to D-D' (figs. 12a-d) at and near Site 3 show the rise in water levels was confined to layer L-15 to L-20. The rise in water levels in wells $43 B R$ and $44 B R$, Section D-D', was a result of the slow recovery after the collection of water samples from the two wells and not the result of turning off the pumps. The changes in water levels at Site 1 in section E-E' to J-J' (figs. 12e-j) show the rise in water levels was confined to layers L-15 to L-21. 


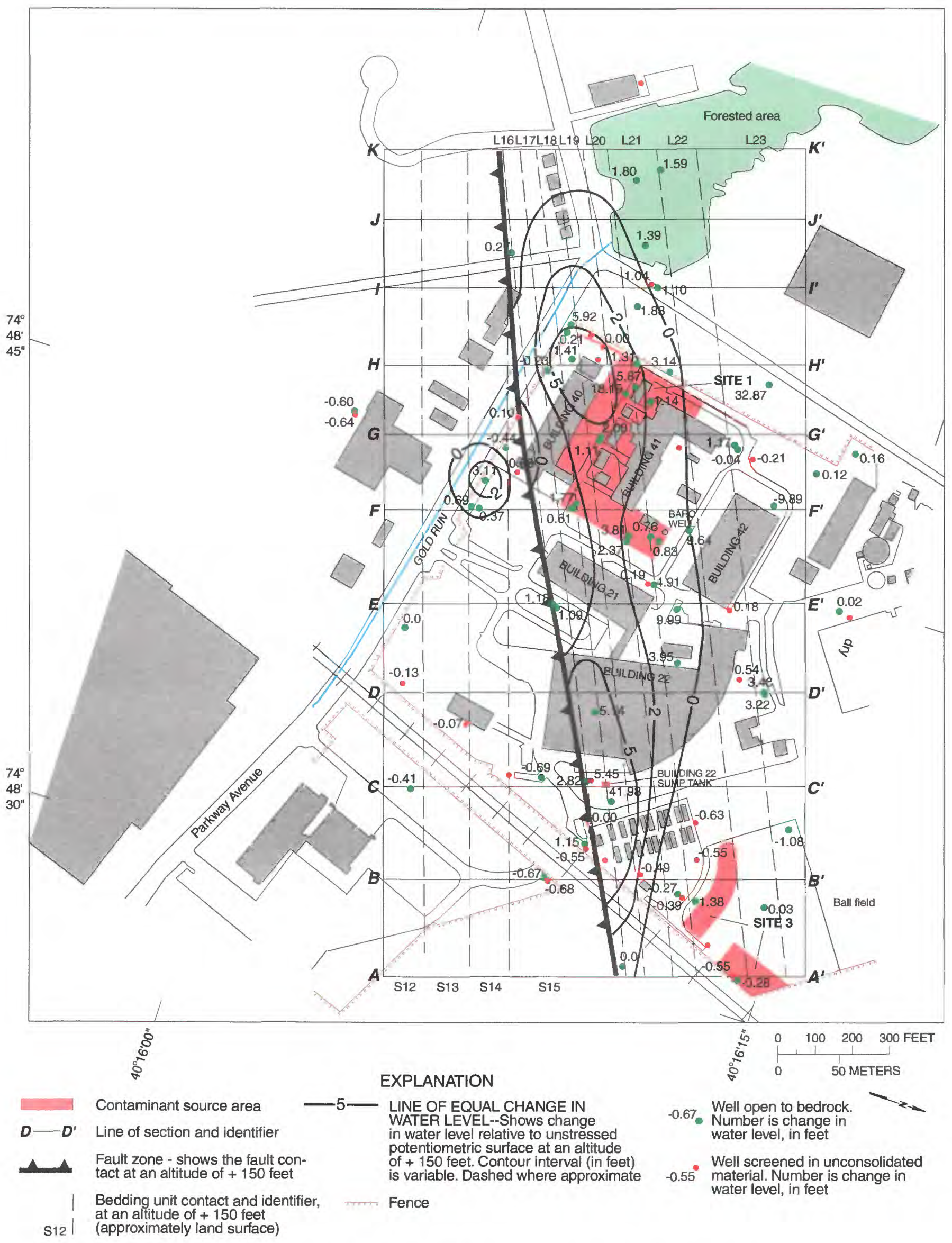

Figure 10. Change in water level at an altitude of +150 feet (approximately land surface), May 18 to October 23, 2000, Naval Air Warfare Center, West Trenton, N.J. 


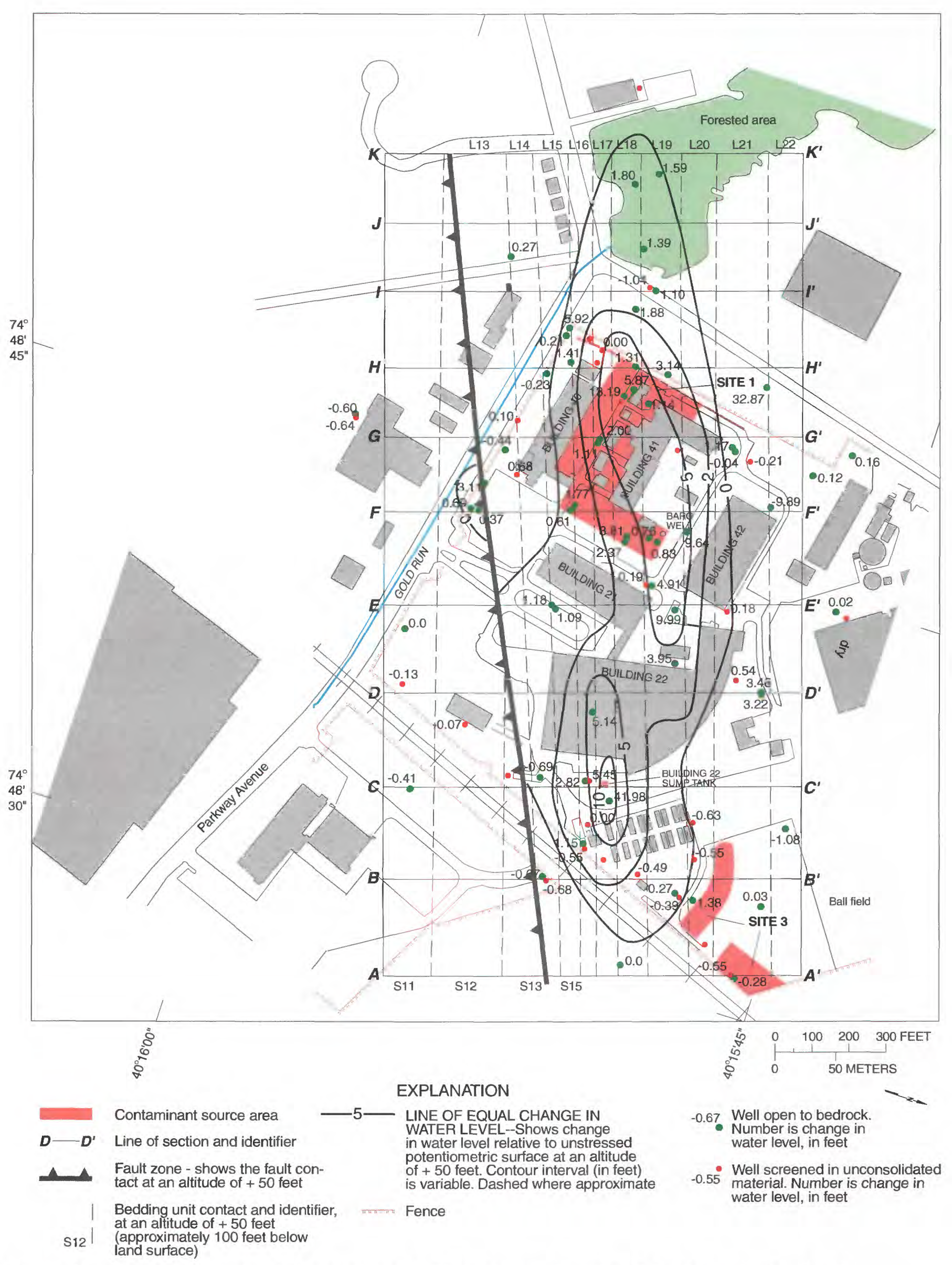

Figure 11. Change in water level at an altitude of +50 feet (approximately 100 feet below land surface), May 18 to October 23, 2000, Naval Air Warfare Center, West Trenton, N.J. 


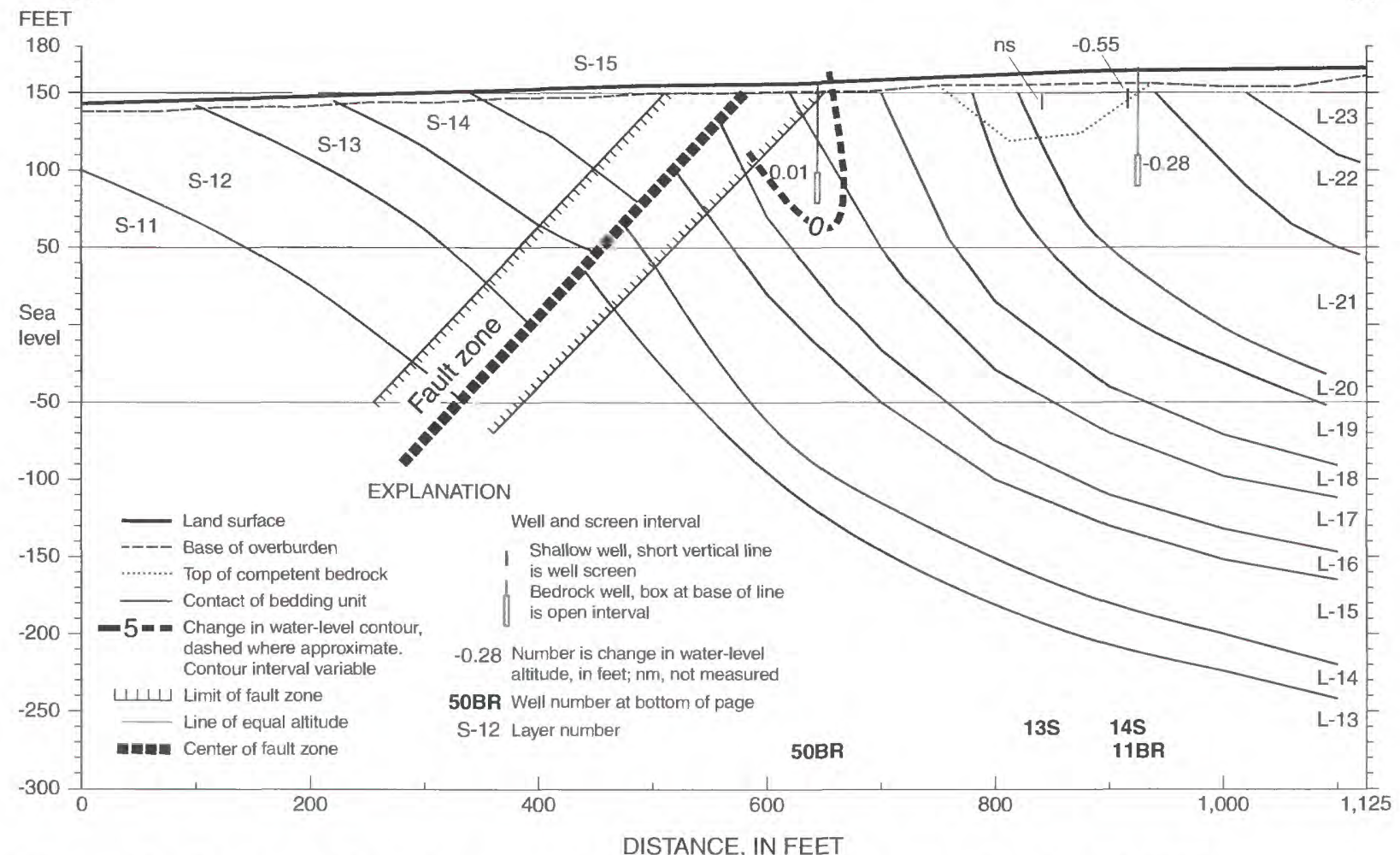

Figure 12a. Section $A-A$ ' showing change in water levels from May 18 to October 23,2000 , Naval Air Warfare Center, West Trenton, N.J.

$B$

FEET

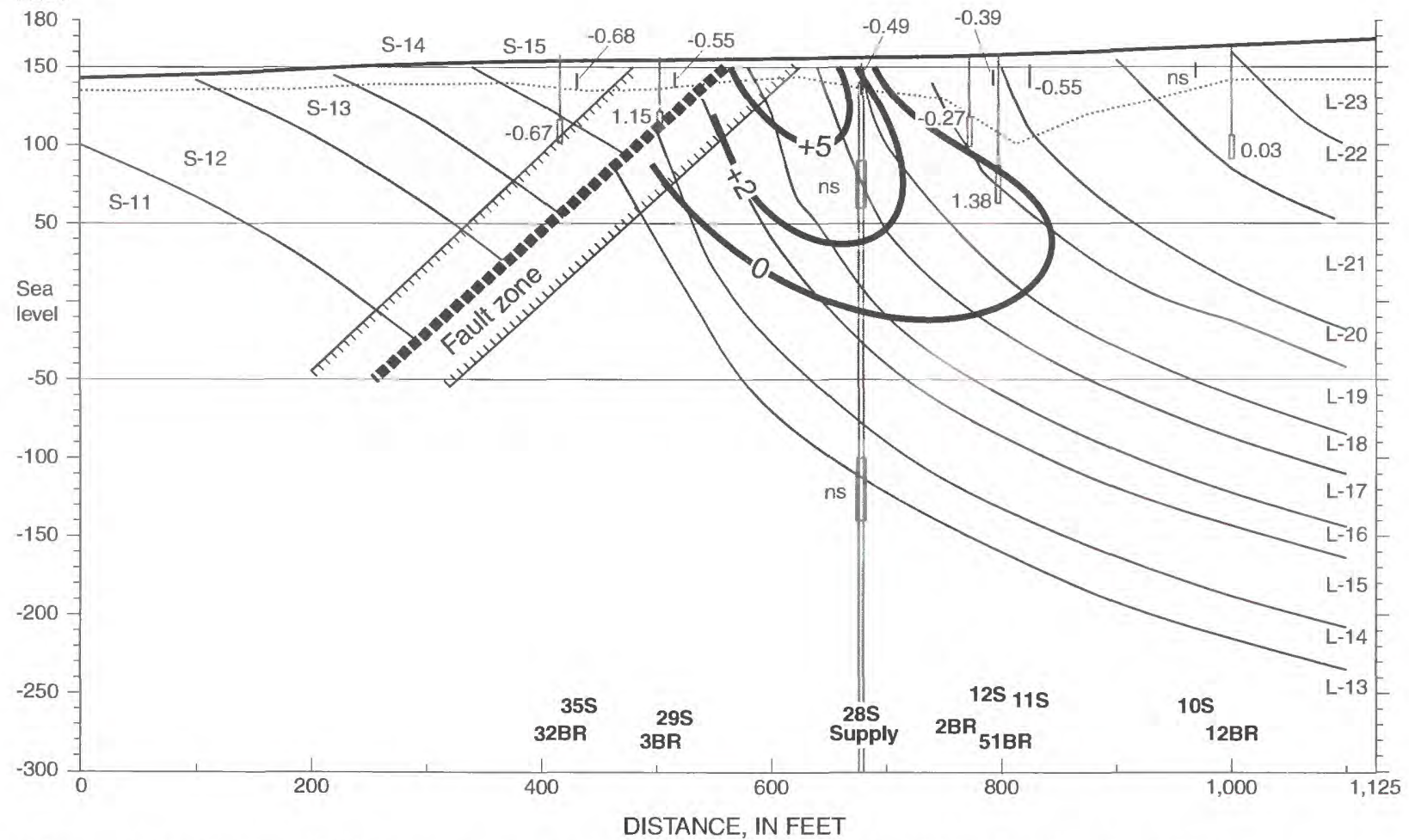

Figure 12b. Section $B-B^{\prime}$ showing change in water levels from May 18 to October 23, 2000, Naval Air Warfare Center, West Trenton, N.J. 


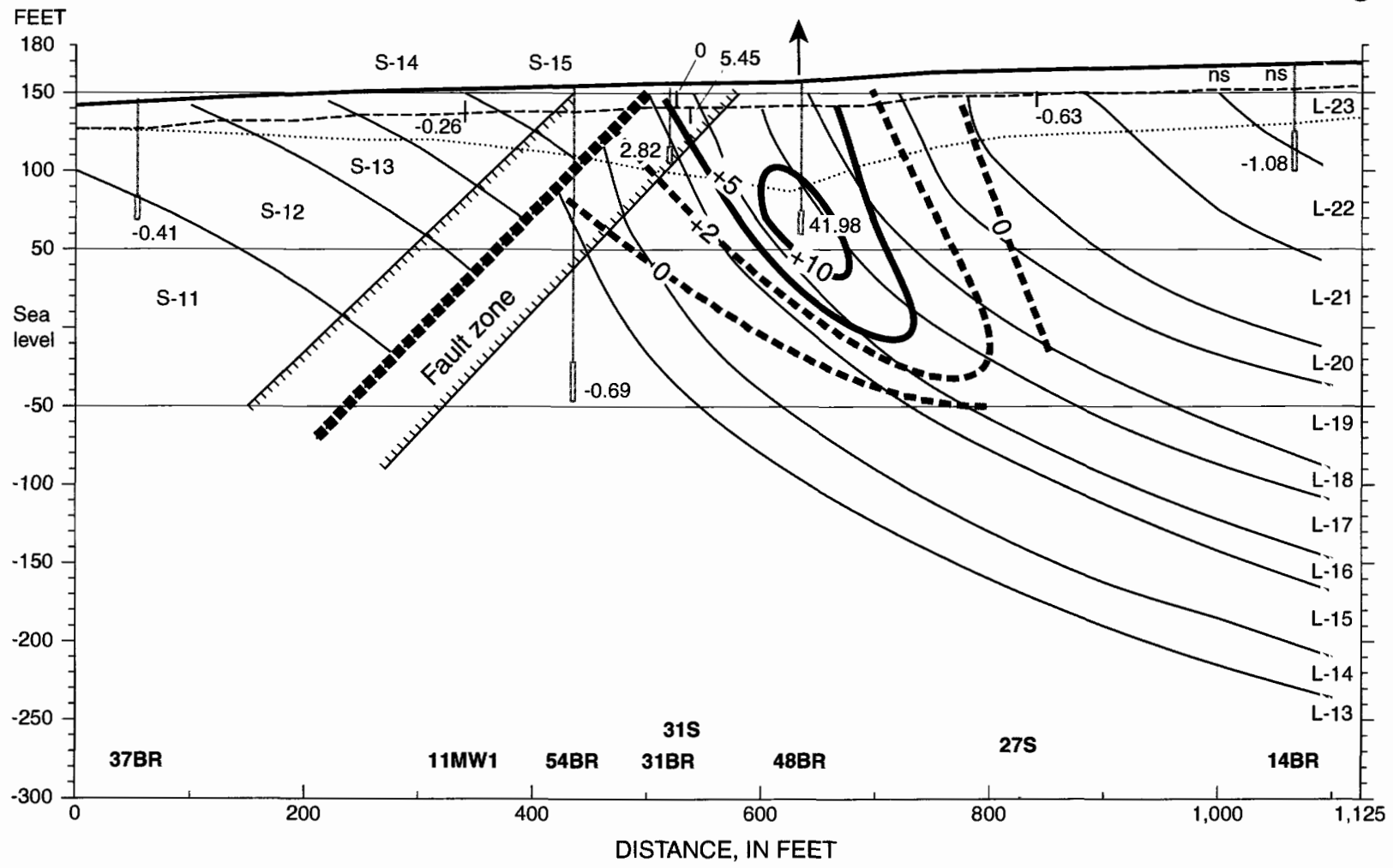

Figure 12c. Section $C-C^{\prime}$ showing change in water levels from May 18 to October 23, 2000, Naval Air Warfare Center, West Trenton, N.J.

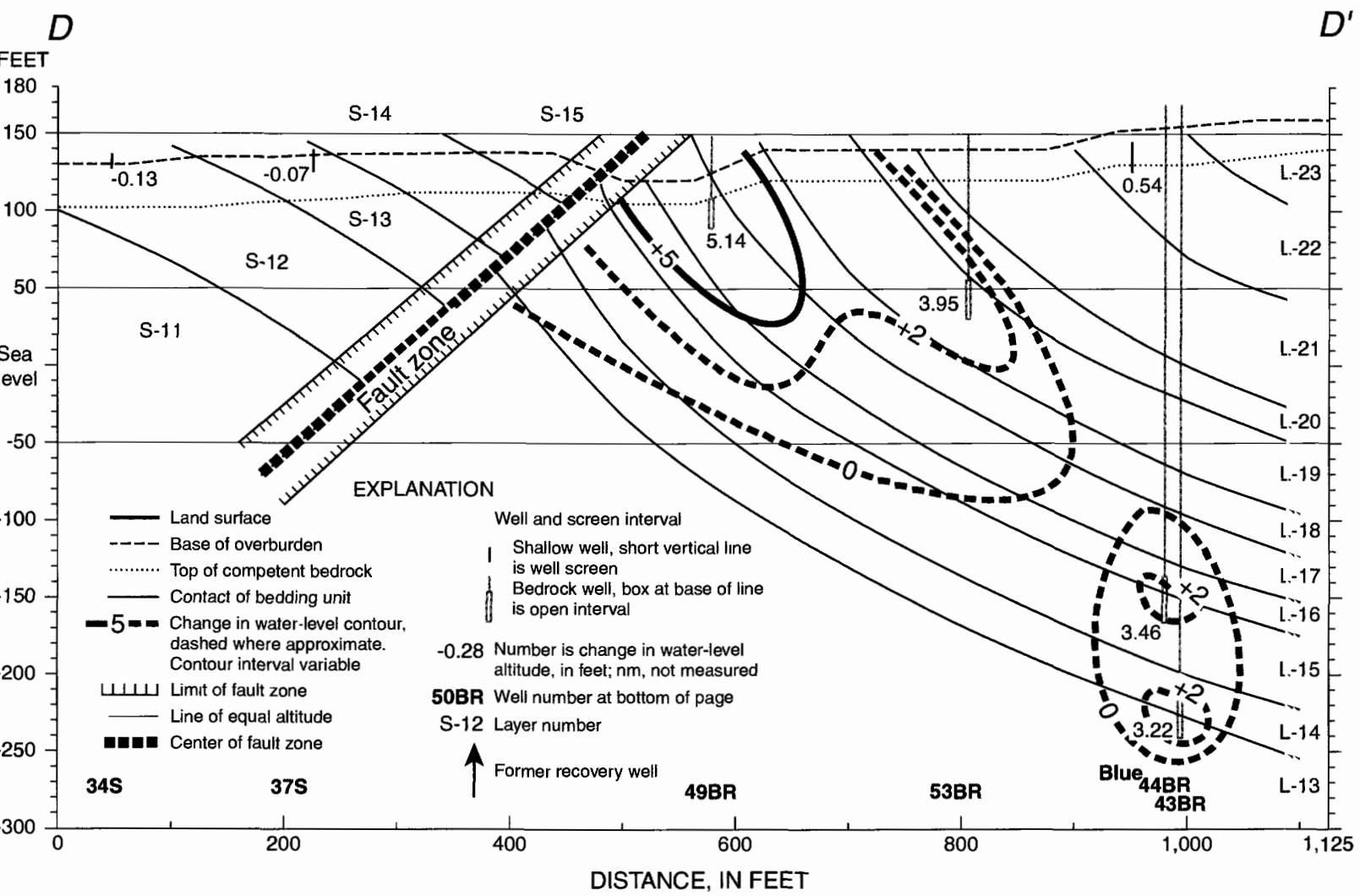

Figure 12d. Section $D-D^{\prime}$ showing change in water levels from May 18 to October 23, 2000, Naval Air Warfare Center, West Trenton, N.J. 


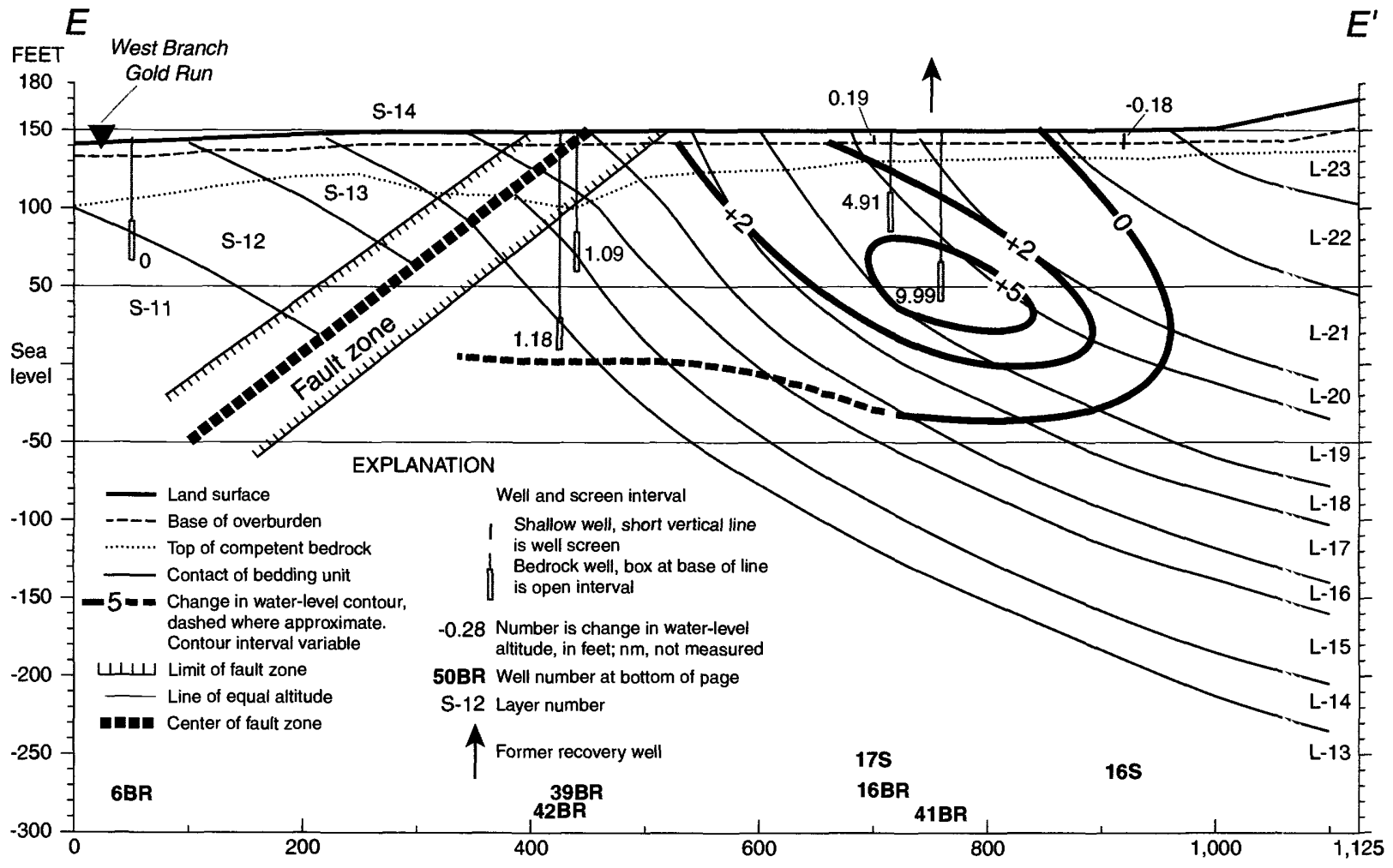

DISTANCE, IN FEET

Figure 12e. Section $E-E^{\prime}$ showing change in water levels from May 18 to October 23, 2000, Naval Air Warfare Center, West Trenton, N.J.

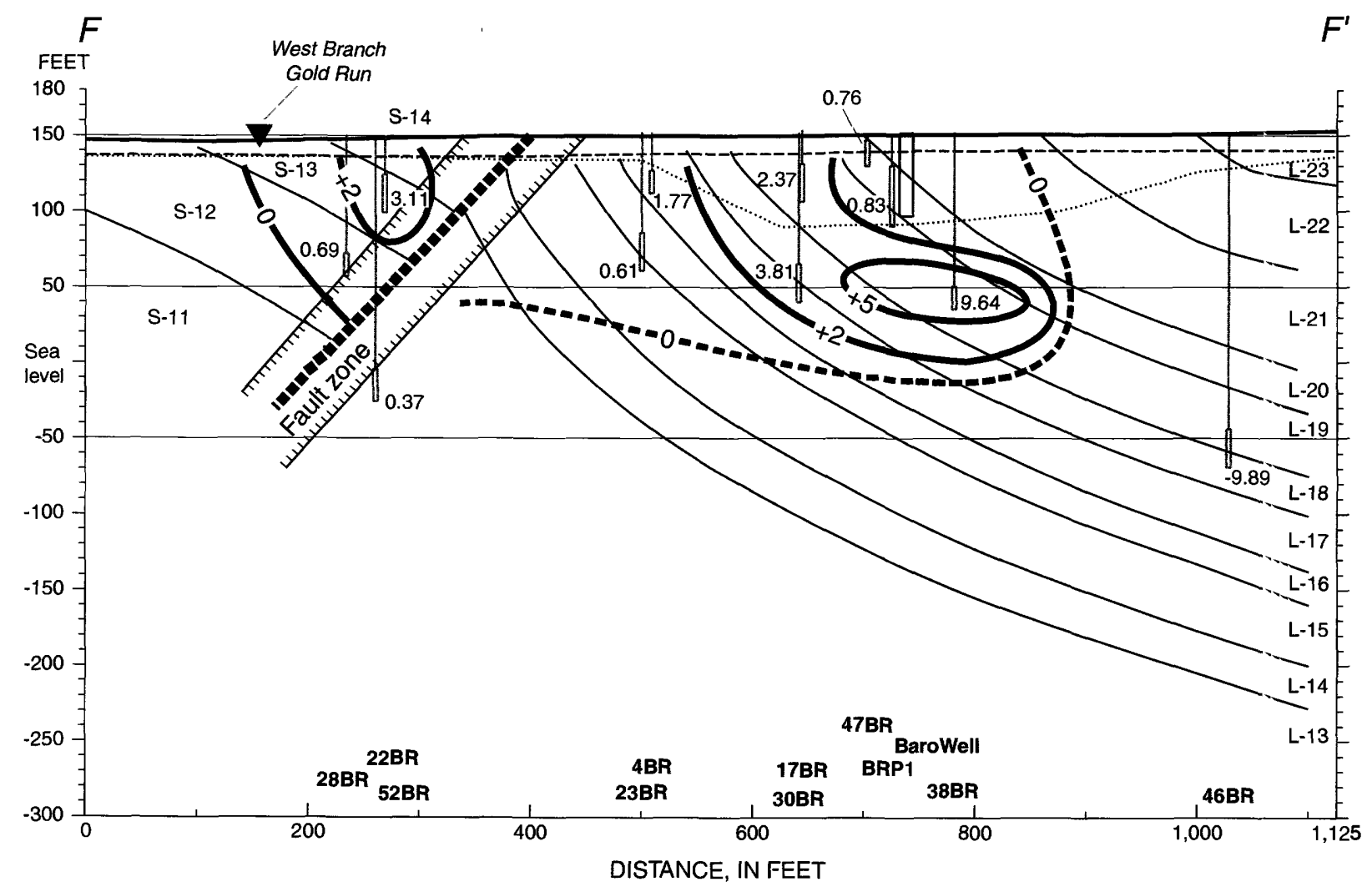

Figure 12f. Section $F-F^{\prime}$ showing change in water levels from May 18 to October 23, 2000, Naval Air Warfare Center, West Trenton, N.J. 


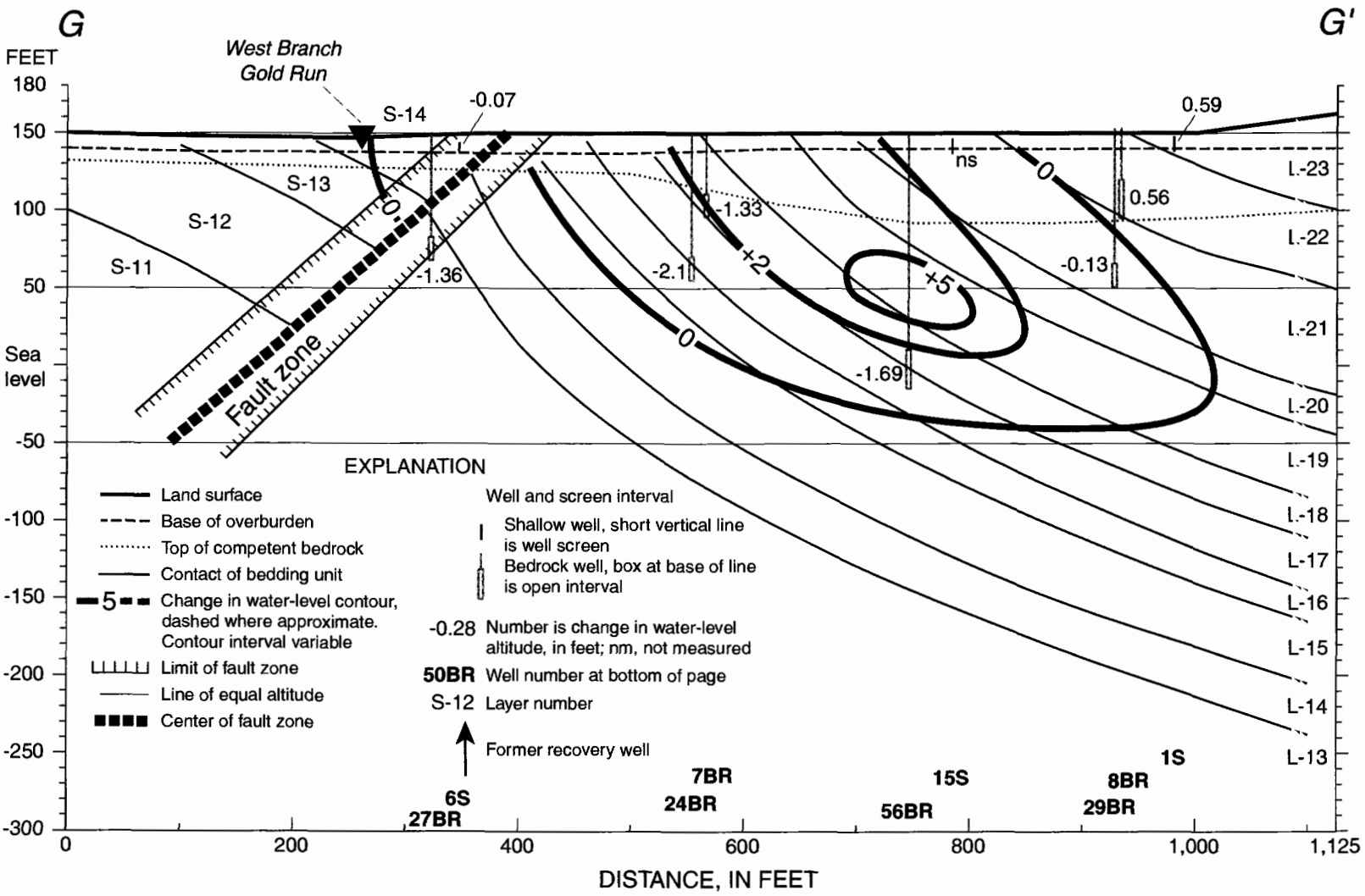

Figure 12g. Section G-G'showing change in water levels from May 18 to October 23, 2000, Naval Air Warfare Center, West Trenton, N.J.

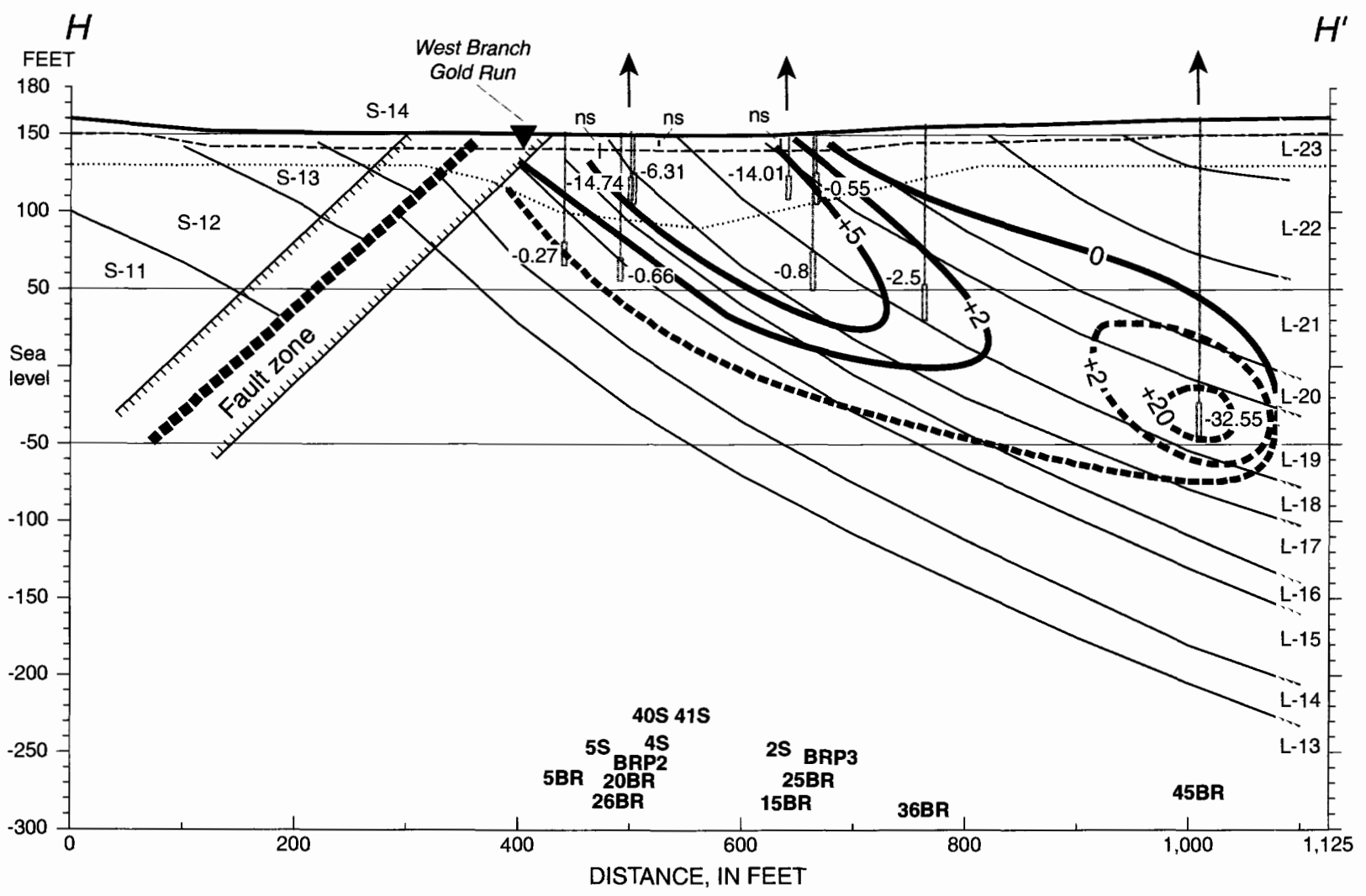

Figure 12h. Section $H-H^{\prime}$ showing change in water levels from May 18 to October 23, 2000, Naval Air Warfare Center, West Trenton, N.J. 


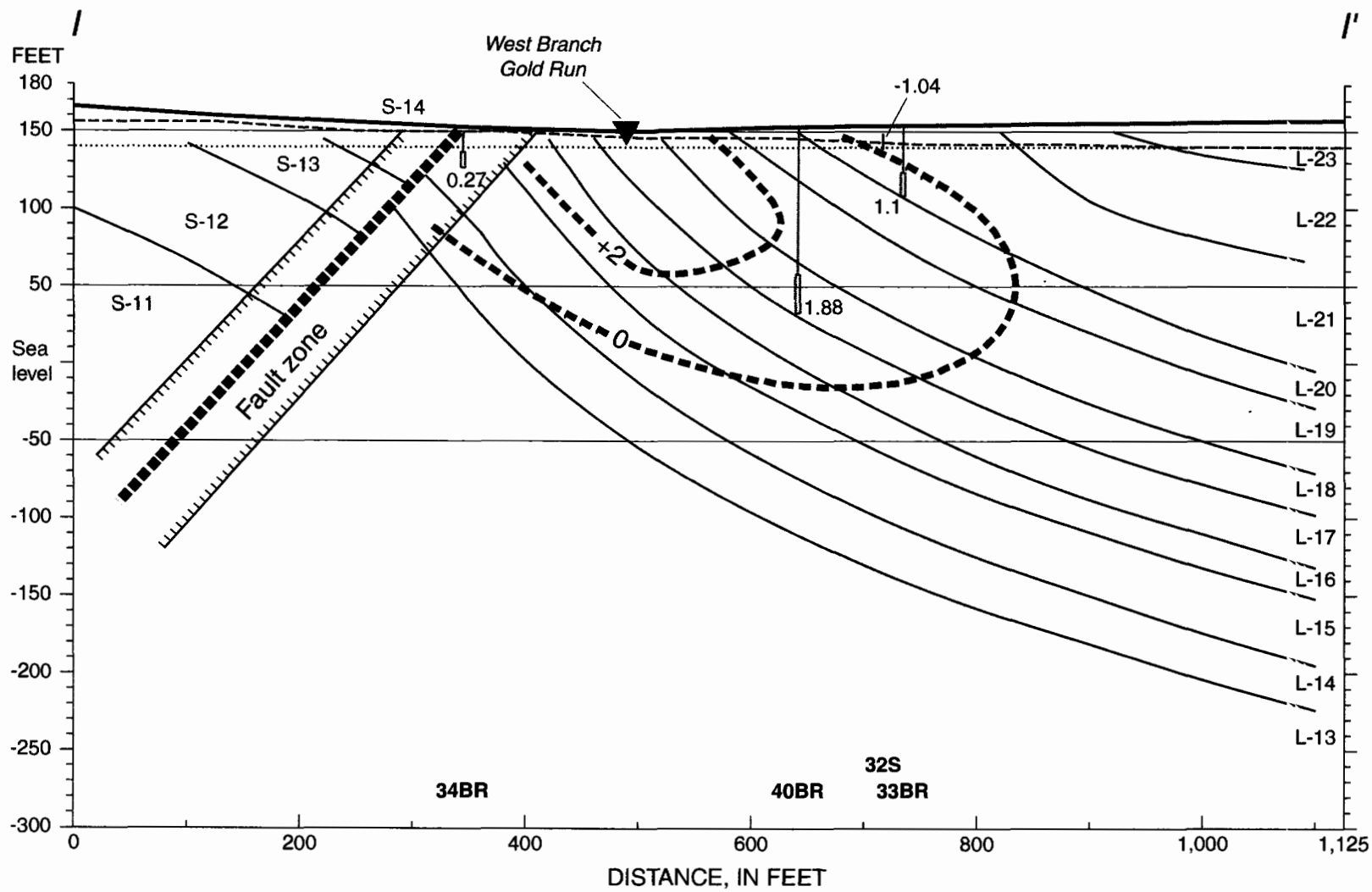

Figure 12i. Section I-I' showing change in water levels from May 18 to October 23, 2000, Naval Air Warfare Center, West Trenton, N.J.

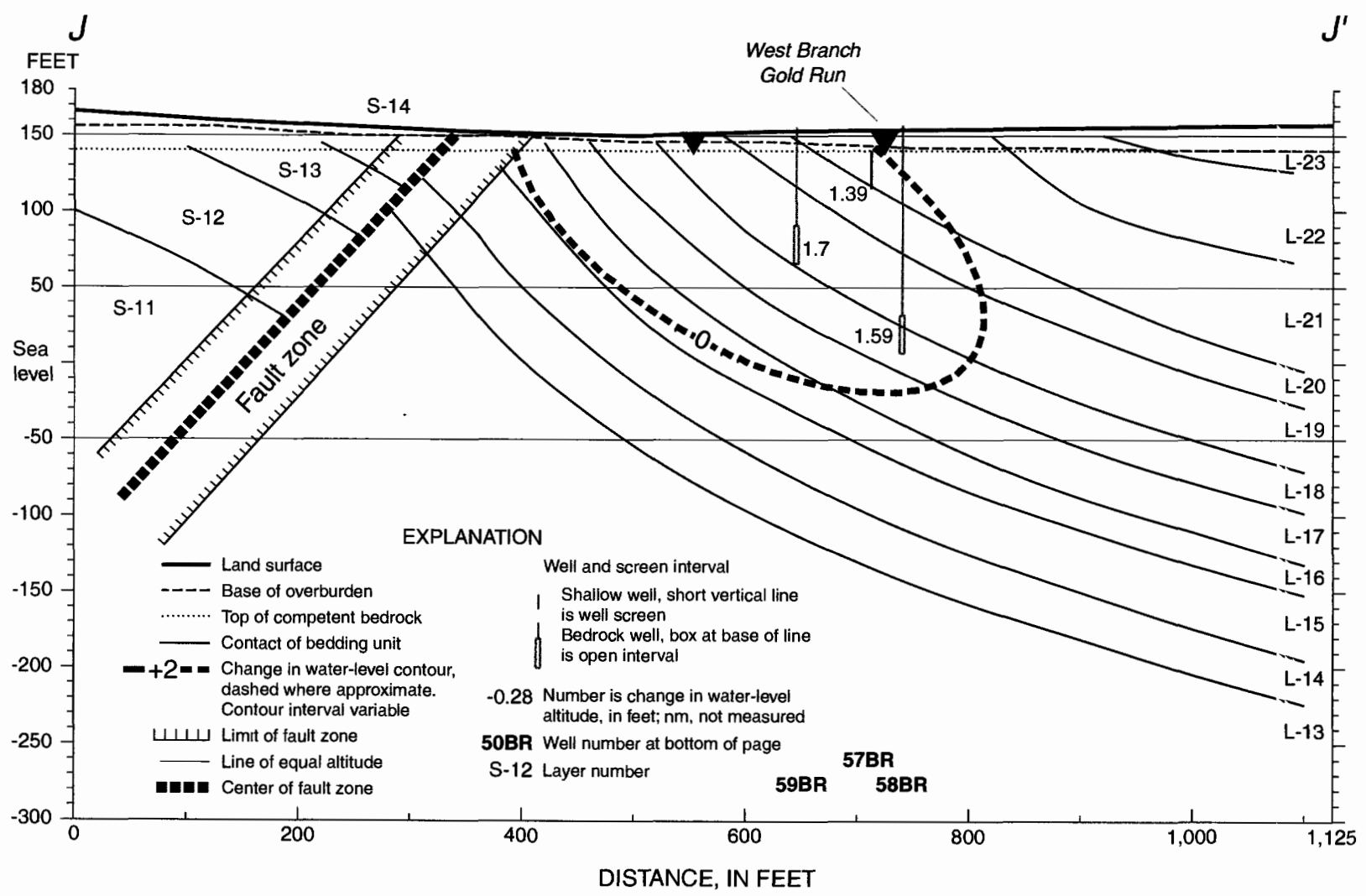

Figure 12j. Section $J-J$ ' showing change in water levels from May 18 to October 23,2000 , Naval Air Warfare Center, West Trenton, N.J. 


\section{SUMMARY}

The U.S. Geological Survey in cooperation with the U.S. Navy conducted this study in 2000 to measure water levels in wells at the Naval Air Warfare Center (NAWC) in West Trenton, New Jersey. Ground water at the 65-acre decommissioned military base has been contaminated with trichloroethylene and other compounds. Water-level data and potentiometric-surface maps and sections are useful for determining the optimal contaminated ground-water withdrawal scheme.

Water levels were measured continuously for most of 2000 in seven wells at the NAWC. In addition, water levels were measured instantaneously in as many as 100 wells on May 18,2000 , and October 23, 2000. Hydrographs for the seven wells show long-term seasonal fluctuations in water levels that are caused by increases and decreases in evapotranspiration. The hydrographs also show short-term changes in water levels that are the result of rainfall and the use of pumps in recovery wells.

Water levels measured on May 18, 2000, show the stressed potentiometric surface while six wells were pumped at a combined rate of about 56 gallons per minute. Maps and sections show an elongated inclined cone of depression is centered on the pumped wells at Sites 1 and 3. The anisotropy of the elongated inclined cone of depression is more than $4: 1$. A small cone of depression has formed around well $28 \mathrm{BR}$ south of the fault.

Water levels also were measured on October 23,2000 , while all well pumps were off to show the static potentiometric surface. Maps and sections show a regional hydraulic gradient from the upland area northwest of Site 3 toward the west branch of Gold Run. Previous static potentiometric surfaces were affected by many sump pumps that operated in the basement of the buildings at NAWC.
Change-in-water-level maps and sections show the difference in water levels from measurements made on May 18 and October 23, 2000. The area with change-in-water-levels greater than $1 \mathrm{ft}$ forms an elongated inclined feature that extends from east of Site 3 to west of Site 1. 


\section{REFERENCES CITED}

EA Engineering, Science, and Technology, Inc., 1995-May, Final Report 1, Site 1 Interim action well monitoring at Naval Air Warfare Center, Trenton, New Jersey: Berkeley Heights N.J., EA Engineering, Science, and Technology Inc., about $100 \mathrm{p}$.

1996-February, Draft Report 5, Site 1 Interim action well monitoring at Naval Air Warfare Center, Trenton, New Jersey: Berkeley Heights, N.J., EA Engineering, Science, and Technology, Inc., about $100 \mathrm{p}$.

2000a-February, Final, Decision document for ground water at the Naval Air Warfare Center, Aircraft Division, Trenton, New Jersey: Berkeley Heights, N.J., EA Engineering, Science, and Technology, Inc., about $50 \mathrm{p}$.

2000b-February, Final, Focused feasibility study for groundwater at the Naval Air Warfare Center, Aircraft Division, Trenton, New Jersey: Iselin, N.J., EA Engineering, Science, and Technology, Inc., about $400 \mathrm{p}$.

2000 c-February, Draft, Ground water remedial action summary report March 1998August 1999, Naval Air Warfare Center Aircraft Division, Trenton, New Jersey: Iselin, N.J., EA Engineering, Science, and Technology, Inc., about $300 \mathrm{p}$.

Hobbs, B. E., Means, W. D., and Williams, P. F., 1976, An Outline of Structural Geology: New York, John Wiley and Sons, Inc., 571 p.

International Technology Corporation, 1994November, Remedial investigation report installation restoration program, Naval Air Warfare Center, Trenton, New Jersey: Edison, N.J., International Technology Corp., 6 volumes.
Lacombe, P.J., 2000, Hydrogeologic framework, water levels, and trichloroethylene contamination, Naval Air Warfare Center, W'est Trenton, New Jersey, 1993-97: U.S. Geological Survey Water-Resources Investigations Report, 98-4167, 139 p.

U.S. Navy, 2000, August, Operating properly and successfully demonstration, Naval Air Warfare Center Trenton, N.J.: Lester, Pa., U.S. Navy, Northern Division, about 200) p. 
